\title{
Stathmin-dependent molecular targeting therapy for malignant tumor: the latest 5 years' discoveries and developments
}

Rong Biaoxue ${ }^{1 *}$, Cai Xiguang ${ }^{2}$, Liu Hua ${ }^{2}$ and Yang Shuanying ${ }^{3}$

\begin{abstract}
Knowledge of the molecular mechanisms on malignant tumors is very critical for the development of new treatment strategies like molecularly targeted therapies. In last 5 years, many investigations suggest that stathmin is overexpressed in a variety of human malignant tumors, and potentially promotes the occurrence and development of tumors. Rather, down-regulation of stathmin can reduce cell proliferation, motility and metastasis and induce apoptosis of malignant tumors. Thus, a stathmin antagonist, such as a specific inhibitor (antibody, small molecule compound, peptide, or siRNA), may be a novel strategy of molecular targeted therapy. This review summarizes the research progress of recent 5 years on the role of stathmin in tumorigenesis, the molecular mechanisms and development of anti-stathmin treatment, which suggest that continued investigations into the function of stathmin in the tumorigenesis could lead to more rationally designed therapeutics targeting stathmin for treating human malignant tumors.
\end{abstract}

Keywords: Cancer, Stathmin, Drug target, Anticancer therapy, Molecular targeted therapy

\section{Background}

With the development of tumor molecular biology, progress of the detection and treatment of cancer has led to an impressive reduction in both mortality and morbidity. However, cancer still remains one of the most clinically challenging disease [1]. And the current first-line chemotherapy options, such as the combination of platinumbased agents with paclitaxel, gemcitabine, vinorelbine, or docetaxel, seems to have reached a plateau of efficacy [2]. Especially, the resistance to traditional chemotherapeutic agents of tumors has become a very challenging problem. Therefore, more knowledge of the signal events of oncogenesis is required for the development of new drugs [1].

Stathmin (also known as Op18, p18, p19, stathmin 1 or metablastin) has been found to be up-regulated in some cancers [3-6] and correlates with cell differentiation, proliferation and migration, especially in solid tumor cells $[7,8]$. Thus, stathmin may be an attractive target for drug

\footnotetext{
*Correspondence: research568rbx@yeah.net

${ }^{1}$ Department of Respiratory Medicine, First Affiliated Hospital,

Xi'an Medical University, Xi'an, China

Full list of author information is available at the end of the article
}

design as targeting this molecule could simultaneously inhibit several aspects of tumor progression. Five years ago, Barbara Belletti [5] and Shushan Rana [6] made a summing up of relationship between stathmin and cancer. However, recent 5 years, many other studies referring the expression, mechanism and signal pathways of stathmin in tumors have been continuously reported, and some of them are very marked and impressive. It seems that this is an urgent request for cardinal significance that reviews the latest 5 years reports on new progress of this field. Here, we recapitulate the multiple roles of stathmin in cancer progression, the mechanisms and signal pathways of regulating the proliferation, apoptosis, migration of tumor cells, the pre-clinical results of stathmin inhibition in various cancer models, and available data as rationale for the therapeutic manipulation of stathmin in cancer patients.

\section{Stathmin: molecular structure and function domain} In spite of many years of research, knowledge of this molecule is still so obscure that some investigators even did not define its name certainly, which dues to the fact that it is identified independently in many different research 
institutes. So, it is called by different names (e.g., p17, p18, p19, $19 \mathrm{~K}$, metablastin, oncoprotein 18, LAP18, and stathmin 1, Op18/stathmin). Stathmin is composed of 149 amino acids, which are organized into four domains (I-IV), and the core region (amino acids 42-126) is site for tubulin interaction with the additional requirement of either an N- or C-terminal extension [9]. The members of stathmin family belong to microtubule-regulating proteins, which include stathmin (stathmin 1), SCG10, SCLIP, and RB3/RB3'/RB3"coded by four different genes [9]. And, all stathmin family members have a highly conserved stathmin-like domain. The stathmin-like domains of these proteins also possess a tubulin binding activity (Fig. 1).

The N-terminal and C-terminal of stathmin exert different functions when stathmin participate the molecular actions. The $\mathrm{N}$-terminal of stathmin is the regulatory domain of stathmin. There are four phosphorylation domains on this region, designated as Ser 16, 25, 38 and 63 [5], which intimately correlate with the functions of stathmin by kinases involved in major intracellular regulatory cascades. The $\mathrm{C}$-terminal is interaction domain of stathmin, which includes a coiled-coil forming a-helical structure, potentially interacting with other different signal proteins to exert biological actions [10]. Stathmin is an ubiquitous cytosolic phosphoprotein, proposes to be a small regulatory protein and a relay integrating diverse intracellular signaling pathways involved in the control of cell proliferation, differentiation and activities [5]. Some downstream target and/or partner proteins participate the modulation process of stathmin and interact each other to exert biological actions through phosphorylation of stathmin (Fig. 1b).

\section{Expression of stathmin in human malignant tumor}

Stathmin expression has been examined in several types of cancer. We emphatically harvested the lasted 5 year studies on this field. As shown in Table 1, stathmin is highly expressed in a variety of assessed human malignancies including lung cancer $[3,11]$, esophageal

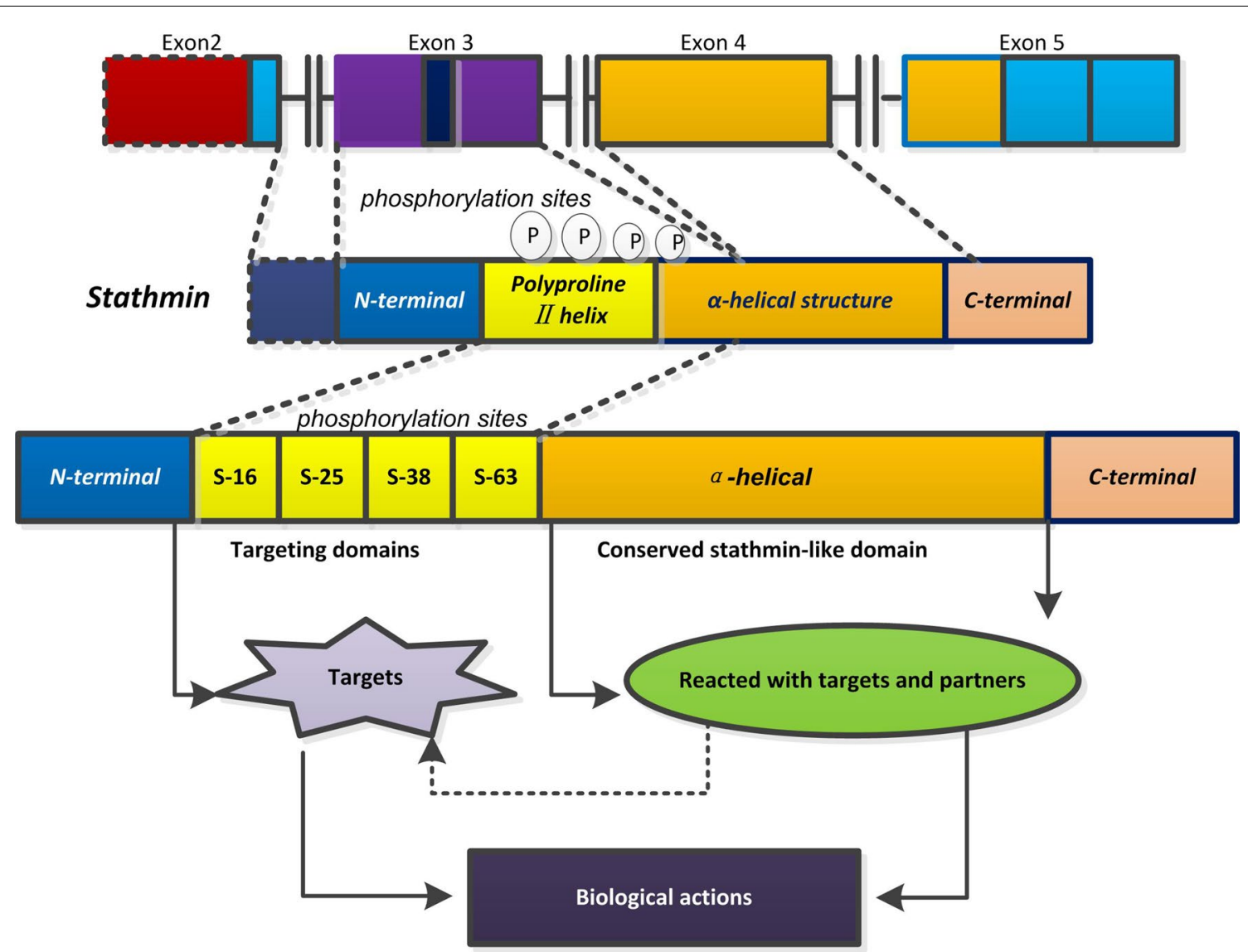

Fig. 1 Structure diagram of stathmin and related signal patterns. Stathmin has a highly conserved stathmin-like domain (a-helical structure) and has four positions of serine phosphorylation sites $(\mathbf{S 1 6}, \mathbf{S 2 5}, \mathbf{S 3 8}$ and $\mathbf{S 6 3})$. The $\mathrm{N}$ - and C-terminal of stathmin exert different functions when stathmin participate the molecular actions. Some downstream target and/or partner proteins participate the modulation process of stathmin and interact each other to exert biological actions through phosphorylation of stathmin 
Table 1 Summary of stathmin expression in human tumors and correlation with clinical outcome

\begin{tabular}{|c|c|c|c|c|c|}
\hline Publications & Cancer type & Cell lines & Tissue & Techniques & Notes \\
\hline Nie [3] & Lung cancer & Yes & Yes & qRT-PCR, IHC & $\begin{array}{l}\text { Overexpression of stathmin is a poor } \\
\text { prognostic biomarker for non-small } \\
\text { cell lung cancer }\end{array}$ \\
\hline Sun [11] & & No & Yes & IHC, WB, qRT-PCR & $\begin{array}{l}\text { Overexpression of stathmin correlates } \\
\text { with shorter overall survival and } \\
\text { progression-free survival in non-small } \\
\text { cell lung cancer }\end{array}$ \\
\hline Wang [15] & Esophageal carcinoma & No & Yes & $\mathrm{IHC}, \mathrm{ISH}$ & $\begin{array}{l}\text { Stathmin is associated with esophageal } \\
\text { carcinoma (EC) development and } \\
\text { progression and may be a good prog- } \\
\text { nostic marker for patients with EC }\end{array}$ \\
\hline Wang [16] & & Yes & Yes & $\mathrm{HC}, \mathrm{WB}$ & $\begin{array}{l}\text { Stathmin is highly expressed in esopha- } \\
\text { geal squamous cell carcinoma Eca109 } \\
\text { and TE-1 cells }\end{array}$ \\
\hline Liu [13] & & Yes & Yes & 2-DE and IHC & $\begin{array}{l}\text { Stathmin is overexpressed in esopha- } \\
\text { geal squamous cell carcinoma (ESCC) } \\
\text { tissues }\end{array}$ \\
\hline Akhtar [12] & & No & Yes & $\mathrm{IHC}, \mathrm{WB}$ & $\begin{array}{l}\text { Stathmin overexpression predicts a high } \\
\text { risk for lymphatic metastatic recur- } \\
\text { rence in pNo esophageal squamous } \\
\text { cell carcinoma patients }\end{array}$ \\
\hline Baquero [17] & Breast cancer & No & Yes & $\mathrm{HC}$ & $\begin{array}{l}\text { High stathmin expression predicts } \\
\text { worse overall survival of breast cancer }\end{array}$ \\
\hline Watanabe [18] & Cholangiocarcinoma & Yes & Yes & $\mathrm{IHC}, \mathrm{WB}$ & $\begin{array}{l}\text { Stathmin correlates with shorter recur- } \\
\text { rence-free survival and overall survival } \\
\text { in cholangiocarcinoma patients }\end{array}$ \\
\hline Hsieh [4] & Hepatocellular carcinoma & Yes & Yes & $\mathrm{HC}, \mathrm{WB}$ & $\begin{array}{l}\text { Stathmin overexpression in hepatoma } \\
\text { is associated with local invasion, early } \\
\text { recurrence, and poor prognosis, and } \\
\text { is an independent indicator for tumor } \\
\text { recurrence }\end{array}$ \\
\hline Ahn [19] & & Yes & Yes & $\mathrm{HC}, \mathrm{WB}$ & $\begin{array}{l}\text { Stathmin and EF1a increase as } \\
\text { multistep hepatocarcinogenesis pro- } \\
\text { gressed, showing the highest levels in } \\
\text { hepatocellular carcinomas }\end{array}$ \\
\hline Chen [20] & & Yes & Yes & $\mathrm{HC}, \mathrm{WB}$ & $\begin{array}{l}\text { Upregulation of E2F1 and stathmin } \\
\text { are associated with worse outcomes } \\
\text { in patients with hepatocellular } \\
\text { carcinoma }\end{array}$ \\
\hline Li [24] & Gastric cancer & Yes & Yes & $\mathrm{HC}, \mathrm{WB}$ & $\begin{array}{l}\text { Stathmin is overexpressed in } 103 \text { post- } \\
\text { operational gastric cancer specimens }\end{array}$ \\
\hline Liu [25] & & Yes & Yes & $\mathrm{IHC}, \mathrm{WB}$ & $\begin{array}{l}\text { Stathmin is elevated in gastric cancer } \\
\text { tissues, indicating a possible associa- } \\
\text { tion between the stathmin and the } \\
\text { disease occurrence }\end{array}$ \\
\hline Batsaikhan [21] & & No & Yes & $\mathrm{IHC}, \mathrm{ISH}$ & $\begin{array}{l}\text { Higher stathmin is significantly associ- } \\
\text { ated with gender-and poorly differen- } \\
\text { tiated gastric adenocarcinoma }\end{array}$ \\
\hline Kang [22] & & Yes & Yes & IHC,WB, qRT-PCR & $\begin{array}{l}\text { Stathmin is upregulated in gastric } \\
\text { cancer cell lines and primary gastric } \\
\text { adenocarcinomas, which is correlated } \\
\text { with age, T stage and lymph node } \\
\text { metastasis }\end{array}$ \\
\hline Ke [23] & & No & Yes & IHC, WB, qRT-PCR & $\begin{array}{l}\text { Stathmin mRNA and protein in gastric } \\
\text { cancer tissues are overexpressed, } \\
\text { which correlates with Lauren's clas- } \\
\text { sification, depth of invasion, lymph } \\
\text { node metastases, and tumor node } \\
\text { metastasis (TNM) stage }\end{array}$ \\
\hline
\end{tabular}


Table 1 continued

\begin{tabular}{|c|c|c|c|c|c|}
\hline Publications & Cancer type & Cell lines & Tissue & Techniques & Notes \\
\hline Lu [27] & Pancreatic cancer & Yes & Yes & $\mathrm{IHC}, \mathrm{WB}$ & $\begin{array}{l}\text { Stathmin is over-expressed in pancre- } \\
\text { atic cancer tissues and correlates } \\
\text { with vascular emboli, tumor size, and } \\
\text { overall survival }\end{array}$ \\
\hline Schimmack [28] & $\begin{array}{l}\text { Pancreatic neuroendocrine } \\
\text { neoplasm }\end{array}$ & Yes & Yes & IHC,WB, qRT-PCR & $\begin{array}{l}\text { Stathmin mRNA and protein are overex- } \\
\text { pressed in pancreatic neuroendocrine } \\
\text { neoplasm (pNENs) and correlate with } \\
\text { pNEN tumor extension, size, and Ki67 } \\
\text { expression }\end{array}$ \\
\hline Li [59] & & Yes & Yes & $\| \mathrm{HC}, \mathrm{WB}$ & $\begin{array}{l}\text { Stathmin is overexpressed to a large } \\
\text { extent in pancreatic cancer tissues } \\
\text { and cell lines }\end{array}$ \\
\hline Machado-Neto [29] & Myelodysplastic syndromes & Yes & Yes & $\mathrm{HC}, \mathrm{WB}$ & $\begin{array}{l}\text { Higher stathmin level is observed in } \\
\text { proliferating hematopoietic cells, } \\
\text { high-risk myelodysplastic syndromes } \\
\text { (MDS) and acute leukemia cells }\end{array}$ \\
\hline Hsu [30] & Nasopharyngeal carcinoma & Yes & Yes & $\mathrm{HC}, \mathrm{WB}$ & $\begin{array}{l}\text { Higher stathmin expression is cor- } \\
\text { related with advanced age higher T } \\
\text { stage and overall clinical stage }\end{array}$ \\
\hline Birnie [31] & Malignant pleural mesothelioma & Yes & No & $\mathrm{IHC}, \mathrm{WB}$ & $\begin{array}{l}\text { Stathmin expression is higher in } \\
\text { malignant pleural mesothelioma cell } \\
\text { lines when compared with primary } \\
\text { mesothelial cell controls }\end{array}$ \\
\hline Howitt [32] & Cervical carcinomas & No & Yes & $\mathrm{IHC}$ & $\begin{array}{l}\text { Stathmin is overexpressed in virtually } \\
\text { all cervical carcinomas and cervical } \\
\text { intraepithelial neoplasias } 3 \text { (CIN3) } \\
\text { lesions }\end{array}$ \\
\hline $\mathrm{He}[33]$ & Endometrial carcinoma & Yes & Yes & $\mathrm{IHC}$ & $\begin{array}{l}\text { Stathmin is up-regulated in endome- } \\
\text { trial carcinoma (EC), and elevated } \\
\text { stathmin is correlated positively } \\
\text { with tumor stage and lymph node } \\
\text { metastasis }\end{array}$ \\
\hline Wik [34] & & Yes & Yes & IHC, FISH, FCM, SNP & $\begin{array}{l}\text { High p-stathmin(S38) level is associated } \\
\text { with poor prognosis, independent of } \\
\text { other features. }\end{array}$ \\
\hline Bhagirath [37] & Bladder urothelial carcinoma & No & No & ELISA, qRT-PCR & $\begin{array}{l}\text { The urinary level of serum stathmin } \\
\text { concentration shows a specific } \\
\text { increase in patients with urothelial } \\
\text { carcinoma of the bladder as com- } \\
\text { pared to the controls }\end{array}$ \\
\hline Wosnitzer [35] & & No & Yes & $\begin{array}{l}\text { Immunophenotype } \\
\text { analysis }\end{array}$ & $\begin{array}{l}\text { Increased total tau (cytoplasmic and } \\
\text { nuclear) and stathmin before intra- } \\
\text { vesical taxane therapy is significantly } \\
\text { associated with decreased recur- } \\
\text { rence-free survival }\end{array}$ \\
\hline Hemdan [36] & & No & Yes & IHC,WB & $\begin{array}{l}\text { High stathmin expression correlates } \\
\text { to shorter disease-specific survival } \\
\text { hazard ratio, elevated p53 and Ki67- } \\
\text { protein levels }\end{array}$ \\
\hline $\operatorname{Tan}[38]$ & Colorectal cancer & Yes & Yes & 2-D DIGE & $\begin{array}{l}\text { Stathmin is found to be highly up- } \\
\text { regulated in colorectal cancer E1 cells } \\
\text { as compared to HCT-116 cells }\end{array}$ \\
\hline Marie [39] & Glioblastoma & Yes & Yes & qRT-PCR & $\begin{array}{l}\text { Stathmin expression is significantly } \\
\text { increased in malignant diffusely infil- } \\
\text { trative astrocytomas compared with } \\
\text { pilocytic astrocytoma }\end{array}$ \\
\hline
\end{tabular}

qRT-PCR real-time quantitative reverse transcription polymerase chain reaction, $I H C$ immunohistochemistry, $W B$ west blotting, ISH in situ hybridization, 2- $D E$ two-dimensional gel electrophoresis, FISH fluorescence in situ hybridization, FCM flow cytometry, SNP single nucleotide polymorphism, ELISA enzyme-linked immunosorbent assay, 2-D DIGE two dimension difference gel electrophoresis, EC esophageal carcinoma, ESCC esophageal squamous cell carcinoma, EF1a EF1a promoter, E2F1 E2F transcription factor 1, mRNA messenger RNA, TNM tumor node metastasis classification of malignant tumours, pNENs pancreatic neuroendocrine neoplasm, Ki67 Ki67 gene, MDS myelodysplastic syndromes, CIN3 cervical intraepithelial neoplasias 3 grades, EC endometrial carcinoma, E1 and HCT-116 colorectal cancer cell lines 
carcinoma [12-16], breast cancer [17], cholangiocarcinoma [18], hepatocellular carcinoma $[4,19,20]$, gastric cancer [21-25], pancreatic cancer [26-28], myelodysplastic syndromes [29], nasopharyngeal carcinoma [30], malignant pleural mesothelioma [31], cervical carcinomas [32], endometrial carcinoma [33, 34], urothelial carcinoma of the bladder [35-37], colorectal cancer [38] and glioblastoma [39]. And, high expression of stathmin intimately correlates with the malignant behavior and clinical features of tumor.

With regard to detection of stathmin, most of the studies adopted two levels of cell and tissues. immunohistochemistry (IHC) analysis for stathmin was adopted by almost every study and some even include west blotting. However, most if not all of the studies are concordant with the notion that stathmin expression and/or activity are up-regulated in human cancer. Specifically, seven studies adopted extra detection of qRT-PCR [3, 11, 22, $23,28,37,39]$ and two adopted the methods of 2-DE [13, 38 ], which are all belonged to available methods. Impressively, stathmin overexpression is associated with poor survival and local or distant metastasis formation in several types of human cancer including lung cancer [11], esophageal carcinoma [12], breast cancer [17], cholangiocarcinoma [18], hepatocellular carcinoma [4, 20], gastric cancer [22, 23, 25], pancreatic cancer [27] and endometrial carcinoma [33-35, 37]. These data strongly indicate that stathmin has a potential to become a prognostic index and tumor marker for malignant cancers.

However, there are some limitations on these studies. First, only surgical specimens were used in some studies, which results in a major patient selection bias. Second, the number of samples of some studies is relatively small. Thus, further investigations into different cancers extensively involving a larger number of samples of patients is required to reach a more definitive conclusion. Despite all this, these studies elucidate that stathmin potentially contributes to tumor development and progression, suggesting that its high expression is not only required, but also detrimental during stages of cancer onset [40].

\section{New progress regarding to biological function of stathmin on malignant tumor \\ Stathmin interferes with microtubule dynamics on cancer cells}

This part mainly describes the relationship between regulation of microtubule dynamics and role of stathmin in malignant tumors, as well as prospects or proposals of research. Microtubules are essential for the structure and function of the cell that relate to intracellular transport, cell motility and polarity [6]. When cell turns into mitosis, microtubules become the major component of mitotic spindle which enables correct chromosome segregation [10]. As shown in Fig. 2a, the alteration of microtubules is tided up with many crucial processes such as cell proliferation, mitosis and motility, which is controlled by the phosphorylation of stathmin by two phases causing biphasic shifts in microtubules stability/instability [41]. Epithelial-mesenchymal transition (EMT) plays a positive role in growth and migration of tumor cells. As a microtubule-destabilizing protein, stathmin can promote malignant potential for cancer cells by initiating EMT [10]. Research shows the microtubule-destabilizing activity of stathmin contributes to EMT via stathmin-microtubule-EMT (S-M-E) axis during cancer development [10]. Phosphoinositide 3-kinase PI3 K/mTOR/HSP90 is shown as a possible signal target for p-stathmin S38- high-endometrial cancer cases. High p-stathmin (S38) correlates with PI3 K pathway and increase PIK3CA copy number (FISH) and a PI3 K activation score [34].

Siva1, an apoptosis-inducing factor, inhibits stathmin's activity directly as well as indirectly through $\mathrm{Ca}(2+)$ / calmodulin-dependent protein kinase II-mediated phosphorylation of stathmin at Ser16, which enhances the formation of microtubules and impedes focal adhesion assembly and EMT. And low levels of Siva1 and Ser16phosphorylated stathmin correlate with high metastatic states of human breast cancer cells [42]. The p90 ribosomal S6 kinase 2 (RSK2) has been identified to promote tumor metastasis; latest one study demonstrates that RSK2 directly phosphorylates stathmin and regulates microtubule polymerization to provide a pro-invasive and pro-metastatic advantage to cancer cells [43].

One potential target of the MAPKs is stathmin and the activity of MAPK is induced by the Epstein-Barr virusencoded latent membrane protein 1 (LMP1). Research shows LMP1 regulates stathmin signaling, which is mainly mediated by ERK. The inhibition of LMP1 expression attenuates the interaction of ERK with stathmin and promotes microtubule depolymerization [44]. Stathmin depletion causes significant inhibition of HGF-induced WAVE2 transport and lamellipodia formation. Pak1 plays a critical role in this effect on phosphorylation and recruitment of tubulin-bound stathmin/Op18 to the complex [45]. Stathmin silencing also reduces the activity of CDC25, Aurora A and Plk1. Research shows MTs contribute to Plk1 activation, and stathmin regulates mitotic entry via MTs to control localization and activation of both Aurora A and Plk1 [46] (Fig. 2b).

In the interphase of cell cycle, increased stathmin damages nucleation from centrosome. Homo sapiens leucine rich repeat containing 4 (LRRC4) is epigenetically inactivated commonly in glioma. Knockdown of stathmin induces cell cycle arrest of glioma U251 cells and increases the microtubulin polymerization of U251 

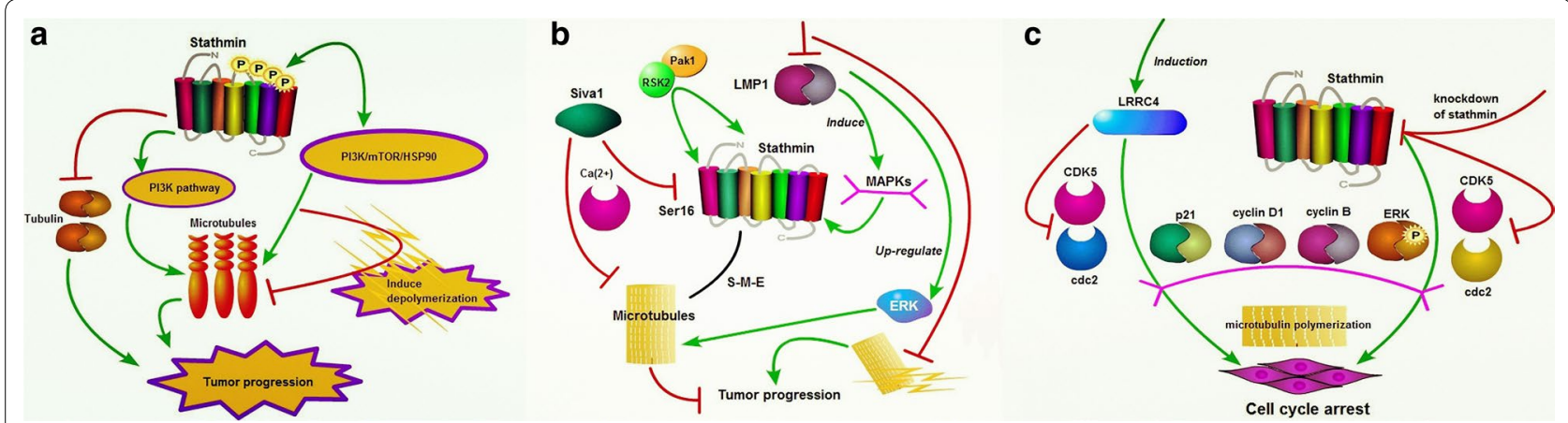

Fig. 2 Stathmin interferes with microtubule dynamics. aThere is a stathmin-microtubule-EMT (S-M-E) axis during cancer development; stathmin promotes malignant potential in cancer cells by initiating EMT; phosphoinositide 3-kinase (PI3 K)/mTOR/HSP90 are suggested as possible targets in p-stathmin(S38)-high cases; b siva1 enhances the formation of microtubules and impedes adhesion, cell migration, and EMT by inhibiting stathmin's activity; inhibition of LMP1 expression attenuates the interaction of ERK with stathmin and promotes microtubule depolymerization; c induction of LRRC4 or knockdown of stathmin induces cell cycle arrest by modulating the p21, cyclin D1, and cyclin B expression, and the ERK phosphorylation. PI3 K phosphoinositide 3-kinase, mTOR mammalian target of rapamycin, HSP90, heat shock protein 90, EMT epithelial-mesenchymal transition, Siva proapoptotic protein, LMP1 latent membrane protein 1, ERK extracellular regulated protein kinases, RSK2 p90 ribosomal S6 kinase 2, LRRC4 leucine rich repeat containing 4, CDK5 cyclin-dependent kinase-5, CDC2 cyclin-dependent kinase 1, p21 cyclin-dependent kinases

cells. And down-regulation of stathmin inhibits CDK5 and cdc2 kinase, which correlates with the modulation of the $\mathrm{p} 21$, cyclin D1, and cyclin B expression, and the situation of ERK phosphorylation [47] (Fig. 2c). Overall, the microtubule-destabilizing protein stathmin is involved in cancer development. Most interestingly, stathmin and its microtubule-depolymerizing activity intimately correlate with EMT progress, which is involved in tumor malignant progression and recurrence, even in resistance of chemotherapy. Thus, further investigations into this process of stathmin-microtubule dynamics should be done.

\section{Stathmin correlates with proliferation of cancer cells}

Stathmin is an important member of a family of microtubule-destabilizing proteins [48], which has been proved to exert critical actions in control of cell proliferation [5]. Several observations suggest that there is a close link between stathmin expression and/or phosphorylation and regulation of cellular proliferation in cancers. Knockdown of stathmin leads to cell cycle arrest in G2/M phase in esophageal carcinoma cells [16] and pancreatic cancer cells and clonogenicity of Namalwa leukemia cells [29], and reduces the viability and colony formation. Adenovirus-mediated gene transfer of anti-stathmin ribozyme results in a dose-dependent inhibition of proliferation and clonogenicity associated with a G2/M arrest and increases the apoptosis rate of both ER-positive and ER-negative breast cancer cells [48]. The CDK inhibitor p27(kip1) and p21(Cip1/Waf1) are critical regulators of cell cycle progression, which bind to stathmin as partners to control the early phase of $\mathrm{G} 1$ to $\mathrm{S}$ phase transition to the context of tumor progression [49]. Knockdown of stathmin results in a decrease in cellular proliferation and invasion in lung cancer cells [3] and in pancreatic neuroendocrine neoplasm cells, and PI3 K inhibitors directly inhibits proliferation via stathmin inactivation [28]. Furthermore, silence of stathmin down-regulates the expression of Nf-kB (p65), which indicates that stathmin might play its oncogenic role by an interaction with $\mathrm{Nf}-\mathrm{\kappa B}$ pathway [27] (Fig. 3a).

Stathmin depletion suppresses the expression of hypoxia-induced factor- $1 \alpha$ (HIF-1 $\alpha$ ) and VEGF, and impedes the phosphorylation of ribosomal protein $\mathrm{S} 6$ kinase 1 ( $\mathrm{S} 6 \mathrm{~K}$ ) and Akt, which means stathmin play a critical role in the mTOR/HIF- $1 \alpha /$ VEGF signally pathway [50]. At molecular level, stathmin favours the binding and the phosphorylation of $\mathrm{p} 53$ (MUT) by catalytic subunit of the DNA-dependent protein kinase (DNA-PK $\mathrm{CS}_{\mathrm{CS}}$ ), modulating p53(MUT) stability and transcriptional activity. Inhibition of stathmin or impediment of DNA-PK $\mathrm{CS}$ damage the p53(MUT)-dependent transcription lead to the failure of $\mathrm{M}$ phase and the death of epithelial ovarian carcinomas (EOC) cells [8] (Fig. 3b). The down-regulation of leucine zipper transcription factor (CREB1) and helix-loop-helix transcription factor (LYL1) reduce the expression of stathmin, which lead to inhibition of cell proliferation [51]. Knockdown of stathmin promotes the effects of indoly-chalcones CITs (CIT-026, CIT-214, CIT223) to bring down microtubule destabilization, result in cell death and decelerate cell proliferation [52]. In addition, stathmin enhances the growth and invasion of endometrial carcinoma cells by regulating the secretion and activation of MMP2 and MMP9 [33]. And inhibition of Rlim (a Ring H2 zinc finger protein) increases the expression of stathmin, and leads to cell proliferation of human osteosarcoma cell lines [53]. Monoclonal antibodies 

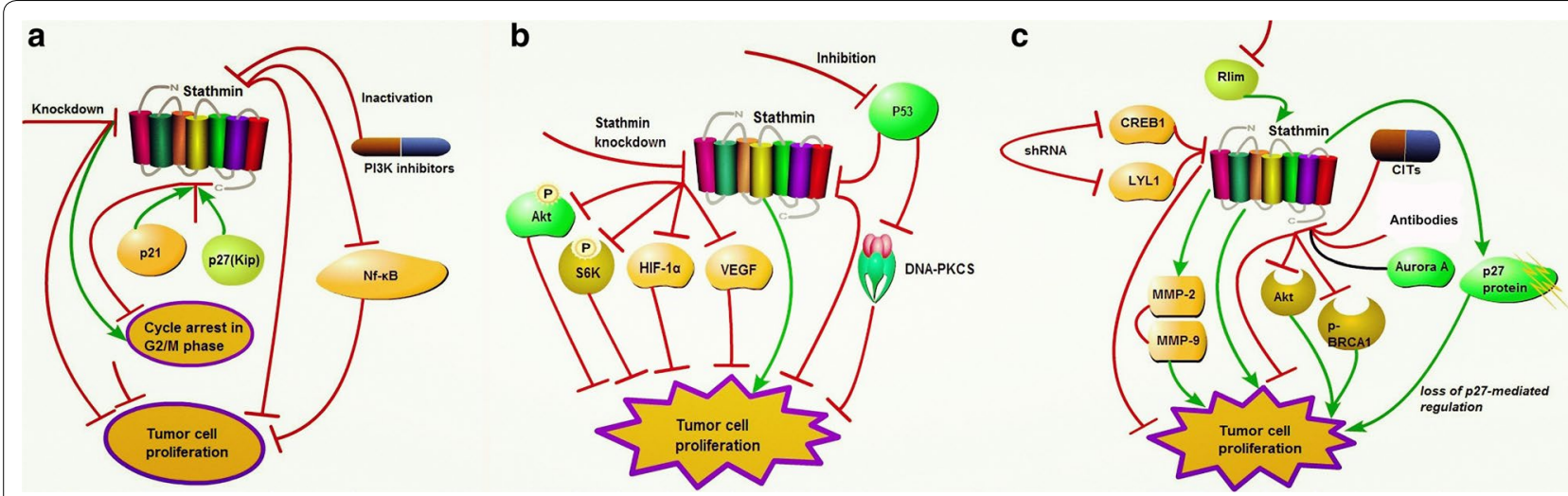

Fig. 3 Stathmin affects the proliferation of cancer cells. a Stathmin cooperates with p21 (Cip1/Waf1) and p27(Kip) to control the early phase of G1 to $S$ phase and reduces tumor growth by down-regulation of Nf-KB; $\mathbf{b}$ stathmin knockdown inhibits the expression of HIF-1a and VEGF and phosphorylation of S6 K and Akt; stathmin binds phosphorylation of p53(MUT) by DNA-PKCS, but inhibition of stathmin or DNA-PKCS results in M phase failure by impairing p53(MUT)-dependent transcription; c down-regulation of CREB1 and LYL1 reduces cell proliferation by the down-regulating stathmin; knockdown of stathmin promotes the effects of indoly-chalcones CITs; stathmin enhances growth and invasion of EC by activating MMP2 and MMP9; inhibition of Rlim increases expression of stathmin and leads to cell proliferation; inhibition of Aurora A by stathmin promoter inhibits cells proliferation by reducing expressions of phosphatidylinositol 3 kinase/Akt and p-BRCA1; stathmin potentiates cell proliferation by regulating function of p27. p21 cyclin-dependent kinases, p27 cell cycle checkpoints regulator protein, P13 K phosphoinositide 3-kinase, Nf-KB nuclear factor 'kappa-light-chain-enhancer' of activated B-cells, Akt v-akt murine thymoma viral oncogene, S6 K ribosomal protein S6 kinase 1, HIF-1a hypoxiainducible factor-1, VEGF vascular endothelial growth factor, $p 53$ tumor suppressor p53, DNA-PKCS catalytic subunit of the DNA-dependent protein kinase, CREB1 leucine zipper transcription factor, LYL1 basic helix-loop-helix transcription factor, Rlim a Ring H2 zinc finger protein, MMP matrix metalloproteinases, $p$-BRCA1 phosphorylated phosphorylated breast cancer gene 1, CITs, indoly-chalcones

against stathmin and paclitaxel have bee used alone or incombination to inhibit the proliferation of human lung carcinoma QG-56 cells, especially result in a significant apoptosis [54]. A novel tumor-specific RNA interference adenovirus system targeting Aurora A by using stathmin promoter not only inhibits the cells proliferation, but also enhance the chemosensitivity to paclitaxel in human breast carcinoma SK-BR-3 and MDA-MB-231 cells, and further decreases the phosphatidylinositol 3 kinase/Akt and p-BRCA1 protein expression [55]. Stathmin also plays a role in the development of fallopian tube epithelium (FTE) tumor, which potentiate aberrant cell proliferation, migration, and/or loss of polarity during early tumorigenesis, resulting from loss of p27-mediated regulation [56] (Fig. 3c).

\section{Stathmin correlates with apoptosis of cancer cells}

Apoptosis, an orchestrated event in which cells are programmed to die after receiving specific stimuli, is an important component of cell growth control [57]. So far, many studies demonstrate that stathmin present an anti-apoptotic activity to prompt the progress of tumor cells and play an important role in control of cell cycles, which are involved in many signal molecules. Oxidative stress from menadione-generated superoxide induces JNK-dependent stathmin phosphorylation at Ser-16, Ser25 and Ser-38 in hepatocytes. Down-regulation of stathmin promotes the sensitivity of apoptotic and necrotic cell death from menadione in hepatocytes [58]. Suppression of stathmin not only inhibits the proliferation, migration and invasion of pancreatic cancer and nasopharyngeal carcinoma cells, but also enhances the apoptosis of cancer cells $[59,60]$. And, stathmin knockdown improves the chemosensitivity of gastric cancer cells to docetaxel, making the percentage of cells at the subG1 stage increase and promote apoptosis [61]. Research shows paclitaxel reduces the expression of stathmin, and combination of stathmin silencing with paclitaxel treatment enhances microtubules polymerization and tumor cell apoptosis [60]. A selective JAK1/2 inhibitor, ruxolitinib, has been reported to inhibit the JAK/STAT pathway in myeloproliferative neoplasms. The JAK2(V617F) mutation potentially leads to inhibition of stathmin activity via constitutive STAT3 phosphorylation. Therefore, combination of stathmin silencing and ruxolitinib treatment can reduce cell proliferation and clonal growth, and increase apoptosis induced by ruxolitinib [62] (Fig. 4a).

Glioma is common angiogenic tumor, which is always resistant to chemotherapy and radiotherapy. Research shows knockdown of stathmin inhibits the proliferation of glioma cells, induces apoptosis, arrests the cell cycle at G2/M phase in glioma stem cells (GSCs), and also suppresses the migration/invasion [63]. Down-regulation of stathmin transfected with stathmin shRNA significantly inhibits cell proliferation and tumorigenicity, arrests cell cycle in the G2/M phase and induces cell apoptosis. 

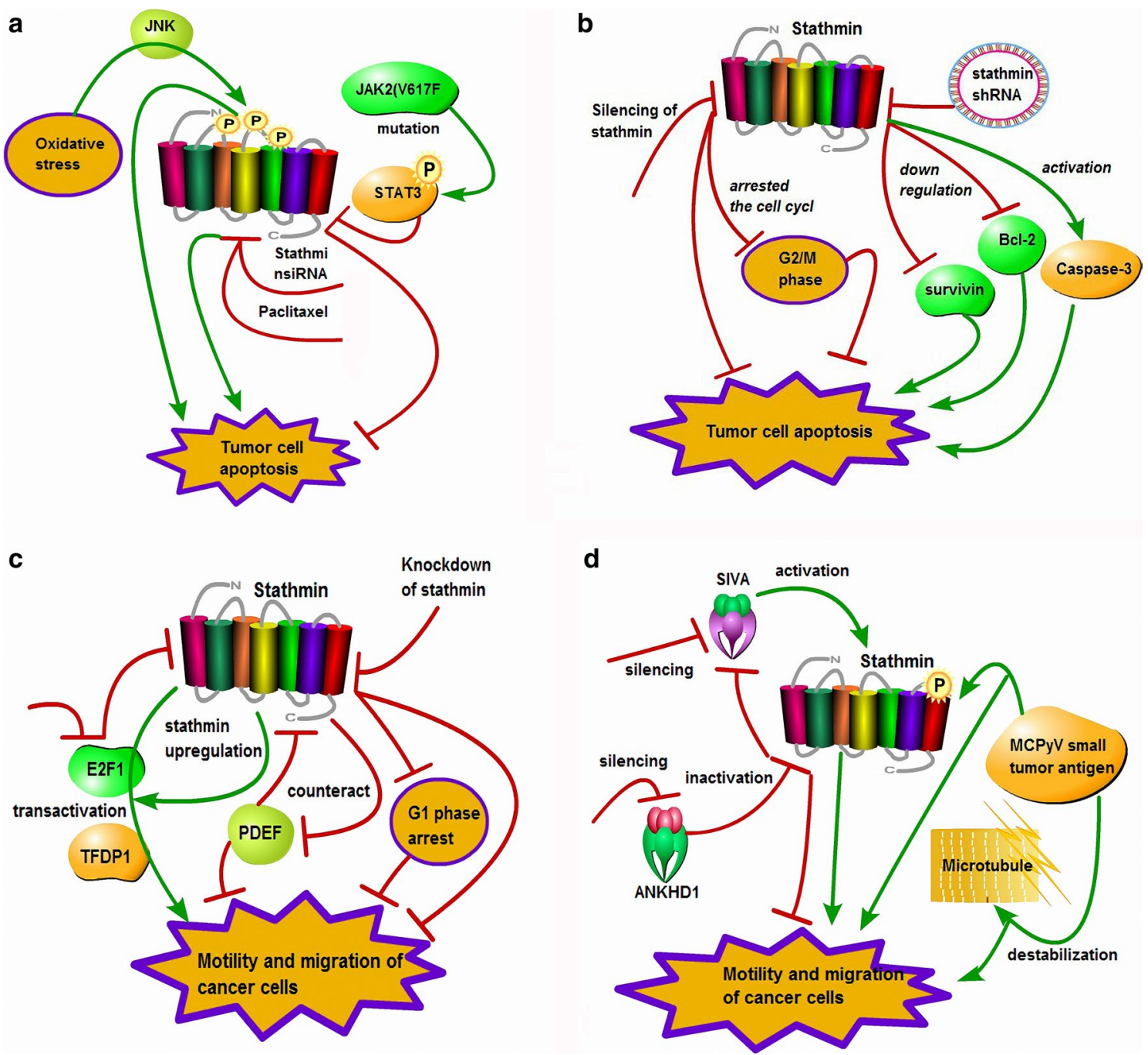

Fig. 4 Stathmin correlates with apoptosis and mobility of cancer cells. a Oxidative stress induces JNK-dependent stathmin phosphorylation, but down-regulation of stathmin promotes apoptosis of cells and inhibits proliferation and migration; stathmin silencing with paclitaxel enhances tumor cell apoptosis; JAK2(V617F) mutation potentially leads to inhibition of stathmin activity via STAT3 phosphorylation; b silencing of stathmin increases apoptosis of cells by down-regulating Bcl-2 and survivin and activating Caspase-3, and significantly arrests the cell cycle at G2/M phase; c stathmin attributes to E2F1 and/or Dp-1 (TFDP1) transactivation, knockdown of the E2F1 suppresses cancer cell migration; stathmin counteracts PDEF's effects against cell migration; d SIVA silencing increases cell migration by promoting stathmin activity, but ANKHD1 silencing leads to stathmin inactivation likely through inhibition of SIVA/stathmin association; MCPyV tumor antigen promotes the destabilization of the host cell microtubule network by regulating phosphorylation of stathmin, which leads to migratory cell phenotype. JNK c-JunN-terminalkinase, JAK janus kinase, JAK janus kinase, STAT signal transducers and activators of transcription, BCl-2 B cell lymphoma-2, E2F1 E2F transcription factor 1, TFDP1 transcription factor Dp-1, PDEF prostate-derived Ets transcription factor, SIVA proapoptotic protein, ANKHD1 ankyrin repeat and KH domain containing 1 protein, MCPyV Merkel cell polyomavirus

Furthermore, down-regulation of stathmin result in downregulation of $\mathrm{Bcl}-2$ and survivin proteins, activation of Caspase-3, which all are intimately related to the development and progress of tumors [14] (Fig. 4b).

\section{Stathmin expression correlates with motility of cancer cells}

The mobility and migration is very critical biological event in progress and proliferation of malignant tumors.
If the tumor cells become migratory, this will possibly lead to the local and remote metastasis of malignant cells, which eventually speed up the disease progress. Stathmin is important member of microtubule-regulating proteins, cell migration is intimately associated with stathmin that interfere with microtubule dynamics by elevating depolymerization of microtubules. Overexpression of stathmin is strongly related to tumor aggressiveness of 
nasopharyngeal carcinoma patients, which attributes to the transactivation of transcription factor 1 (E2F1) and/ or transcription factor Dp-1 (TFDP1) [30]. Down-regulation of E2F1 results in reduction of stathmin in HCC lesions, suggesting that stathmin gene is transactivated by the E2F1 protein [20]. In addition, stathmin silencing significantly impedes cell proliferation and mobility of neuroblastoma cells, polyploidy of hepatoma cells [4] and esophageal squamous cell carcinoma cells [13], and remarkably retards cell migration and invasion [64]. Inversely, over-expression of stathmin enhances cell invasion and causes polyploidy of hepatoma cells [4]. When the expression of stathmin is down-regulated in gastric adenocarcinoma cells, this significantly reduces cell proliferation, colony formation and cell invasion and migration ability, and arrest cells in G1 phase [22]. It is reported that prostate-derived Ets transcription factor (PDEF) is present in breast and prostate cells and tissues. It seems that high expression of stathmin brings down the effects that PDEF inhibit cell proliferation, colony formation and tumor migration, and discloses that PDEF exert an antitumor effects through down-regulating the expression of oncogenic stathmin [65] (Fig. 4c).

It is reported that the knockdown of proapoptotic protein SIVA activates the expression of stathmin, which promotes cell mobility and migration and the growth of xenotransplanted tumors, but silencing of ankyrin repeat and $\mathrm{KH}$ domain containing 1 protein (ANKHD1) plays an inverse function that leads to stathmin inactivation, inhibits cell migration and the growth of xenotransplanted, which possibly depends on the inhibition mechanism of SIVA/stathmin pathway [66]. Merkel cell carcinoma (MCC) can be caused by Merkel cell polyomavirus (MCPyV), which is an aggressive skin malignant tumor, and the migratory mechanism of MCC is more likely related to the function of stathmin. It is shown that MCPyV small tumor antigen enhances microtubule destabilization of the MCC cells by modulating the phosphorylation status of stathmin, which results in the motility, migration and metastasis of Merkel cell carcinoma [67] (Fig. 4d). Although many studies have identified that there is a strong relationship between overexpression of stathmin and increased migration and/ or metastatic trend of malignant tumors; much still has not been disclosed about the molecular signally pathways how stathmin performs the role on migration and metastasis in cancer cells and how stathmin interactions with those special genes and proteins.

\section{Stathmin and small non-coding RNAs}

Recent studies have revealed that small non-protein-coding regulatory RNAs (miRNAs, MicroRNAs) may regulate complex biological processes of malignant tumors including cell proliferation, differentiation and apoptosis. So far, over 2588 miRNAs have been identified in humans and the number of investigations is growing. Evidence on the relation between MicroRNAs and malignant tumor has been suggested that some aberrant miRNA expressions promote the development of cancers, but the others play a negative function in tumorigenesis [68].

The chemoresistant ovarian cancer KF-TX cells present overexpression of stathmin, which is being considered to correlate with drug resistance. Down-regulation of stathmin can partly renew taxane-sensitivity of KF-TX cells, and up-regulation of miR-31 can significantly recover chemo-sensitivity of KF-TX cells (KF-TX-miR-31) by reducing stathmin expression as well [69]. Stathmin is identified as an effective functional target of miR-101, which is related to cell proliferation, radioresistance of nasopharyngeal carcinoma (NPC) cells. The miR-101 exert a critical action in radioresistance by modulating the expression of stathmin via miR-101/stathmin pathway [70]. Down-regulation of miR-193b is closely associated with overexpression of stathmin in melanoma, which is identified to be conducive to promote the migration and proliferation of tumor cells [71]. And study reveals that aberrant miR-223 contributes to aggressiveness of malignant pleural mesothelioma (MPM) by regulating stathmin and both are also in turn regulated by the JNK signally pathway [31] (Fig. 5a).

Elevation of miR-193b impedes the ability of esophageal cancer cells to recover following 5-fluorouracil (5-FU) treatment through the regulation of autophagy, which suggests that it may mediate some of its effects through stathmin regulation (potential autophagy regulator) [72]. Interestingly, overexpression of miR-193b suppresses the proliferation, migration and invasion of pancreatic cancer Panc-1 cells by inhibiting the expression of stathmin and urokinase-type plasminogen activator (uPA) [26]. It is suggested that long term colonization of Helicobacter pylori in gastric mucosa increases the risk of gastric cancer. Stathmin is considered as a target of miR-210 and down-regulation of miR-210 increases the proliferation of gastric epithelial cells by activating stathmin [73]. Specific transfection of miR-142 and miR-223 influences post-transcriptional regulation of proteins in hepatocellular carcinoma (HCCs), which has a suppressive effects on proliferation of hepatocellular carcinoma cells by regulating expressions of stathmin and insulinlike growth factor-1 receptor (IGF-1R) [74] (Fig. 5b).

Stathmin has been identified as a functional target of microRNA-9. Up-regulation of microRNA-9 reduces glioma cell proliferation, migration and vasculogenic mimicry by up-regulating the expression of stathmin [75]. Interestingly, miR-101 expression inhibits the autophagy of hepatocellular carcinoma HepG2 cells by modulating 

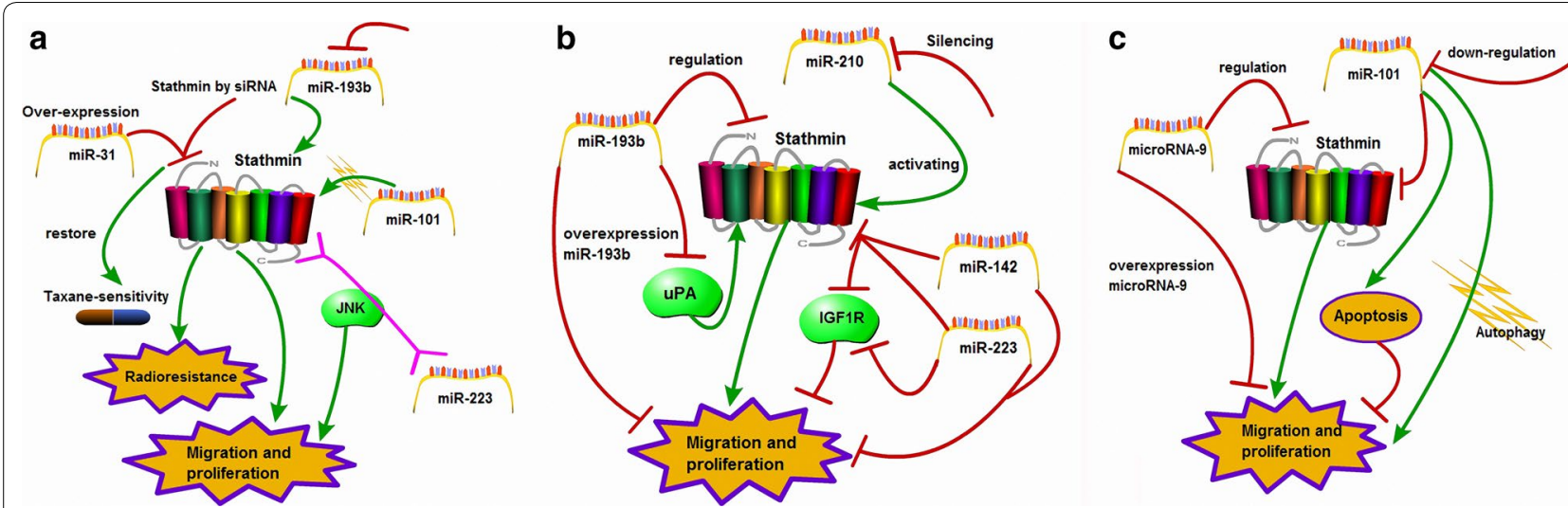

Fig. 5 Study progress of stathmin and MicroRNAs. a Over-expression of miR-31 restores chemo-response by reducing stathmin expression; miR-101/stathmin pathway contributes to radioresistance in human NPC; down-regulation of miR-193b promotes migration and proliferation of tumor cells by targets stathmin; miR-223 regulates stathmin by JNK signaling pathway to regulate MPM cell motility; b up-regulation of miR193b reduces proliferation and migration by inhibiting stathmin and UPA; silencing of miR-210 promotes proliferation of cancerous cells; transfection of miR-142 and miR-223 decreases expression of stathmin and IGF-1R to inhibit proliferation of cancerous cells; c microrna-9 inhibits cell proliferation, vasculogenic mimicry and tumor growth through controlling stathmin expression; miR-101 suppresses autophagy via targets stathmin and downregulation of miR-101 is linked to the increase of cellular proliferation and invasiveness. miRNAs small non-coding regulatory RNAs, JNK c-JunNterminalkinase, UPA urokinase-type plasminogen activator, IGF-1R insulin-like growth factor-1 receptor, MPM malignant pleural mesothelioma

the activity of stathmin, and enhances apoptosis of hepatocellular carcinoma cells by inhibition of autophagy [76]. Another study shows that the expression of miR-101 is negatively correlated with the aggressiveness, growth and angiogenesis in malignant epithelial cancers. Moreover, down-regulation of miR-101 results in the acceleration of cell proliferation and aggressiveness via targeting stathmin, indicating that stathmin is a functional target of miR-101 [77] (Fig. 5c). The clarification of non-coding RNA transcripts is likely conducive to disclose many new mechanisms and pathways for expounding biological phenomena of malignant tumors. Research shows these biological effects of microRNAs on tumors are involved in stathmin signal, influencing the cell cycle control, proliferation, migration and drug resistance. Encouragingly, microRNA molecules are already applying into the clinic as diagnostic and prognostic biomarkers and therapeutic targets and agents.

\section{Stathmin and chemoresistance of cancers}

As shown in Table 2, higher expression of stathmin closely correlates with microtubule-dependent processes and contributes to tumor cell chemoresistance. On the contrary, down-regulation of stathmin significantly reduces the chemoresistance. In this section, studies on relationship between stathmin and chemoresistance of cancers are addressed separately. Recent study demonstrates that overexpression of stathmin influences the efficacy of paclitaxel, suggesting that it can be a negative prognosis indicator for non-small cell lung cancer patients who are treated by both platinum and paclitaxel chemotherapy [11]. NCI-H1299 cells (NSCLC) are evidently resistant to taxol-induced cellular apoptosis and high expression of stathmin is perhaps a crucial determinant of taxol-resistant development in NCI-H1299 cells. Meanwhile, ERK-mediated stathmin is involved in taxol resistance, because blockage of ERK signal improves the sensitivity of tumor cells to taxol $[78,79]$. Over-expression of antiapoptotic protein $\mathrm{Bcl}-2$ has been shown to induce chemoresistance. However, blockade of stathmin and Bcl-2 expression can sensitize lung cancer cells to paclitaxel [80]. Dramatically, knockdown of stathmin combined with paclitaxel remarkably promotes the efficacy of inhibiting proliferation of esophageal squamous cell cancer [81], and leads to a significantly higher proportion of cells at G2/M phase, and this antiproliferative effect was accompanied by an increase in apoptosis rates and morphology changes [82].

After treated by paclitaxel or vincristine, esophageal squamous cell carcinoma (ESCC) cells of stathmin silencing are more likely to enter G2 but less likely to enter mitosis than control cells, suggesting that silencing of stathmin gene increases sensitivity of ESCC to paclitaxel and vincristine through $\mathrm{G} 2 / \mathrm{M}$ phase block [16]. Overexpression of stathmin reduces microtubule dynamicity of cells and sensitivity to taxol, which mainly because overexpression of stathmin protects the cells from taxolinduced abnormal mitoses to lead to taxol resistance [83]. However, combination of anti-stathmin therapy and taxol had a more profound inhibition of tumorigenicity, as both agents target the microtubule pathway [48]. In addition, combined treatment of zoledronic acid and 
Table 2 The research progress of stathmin and chemoresistance

\begin{tabular}{|c|c|c|c|c|c|}
\hline Publications & Cancer type & Cell lines & Tissues & Anticancer drugs & Notes \\
\hline Sun [11] & Non-small cell lung cancer & No & Yes & Platinum; paclitaxel & $\begin{array}{l}\text { High level of stathmin exhibits poor } \\
\text { response to chemotherapy }\end{array}$ \\
\hline $\operatorname{Lin}[78]$ & & Yes & No & Taxol & $\begin{array}{l}\text { Inhibition of stathmin expression increases } \\
\text { sensitivity to taxol and promotes cellular } \\
\text { apoptosis in } \mathrm{NCl}-\mathrm{H} 1299 \text { cells }\end{array}$ \\
\hline $\operatorname{Lin}[79]$ & & Yes & No & Taxol & $\begin{array}{l}\text { ERK-mediated stathmin is involved in taxol } \\
\text { resistance of NCl-H1299 cells; blockage } \\
\text { of ERK signal improves sensitivity of } \\
\text { tumor cells to taxol }\end{array}$ \\
\hline Han [80] & & Yes & No & Paclitaxel & $\begin{array}{l}\text { Inhibition of stathmin and Bcl-2 expres- } \\
\text { sion can sensitize lung cancer cells to } \\
\text { paclitaxel }\end{array}$ \\
\hline Feng [82] & $\begin{array}{l}\text { Esophageal squamous } \\
\text { carcinoma }\end{array}$ & Yes & No & Paclitaxel & $\begin{array}{l}\text { Combined chemotherapeutic agent pacli- } \\
\text { taxel and stathmin siRNA can potentially } \\
\text { enhance the therapeutic outcomes } \\
\text { of paclitaxel in treating esophageal squa- } \\
\text { mous cell cancer (ESCC) }\end{array}$ \\
\hline Wang [16] & & Yes & No & Paclitaxel & $\begin{array}{l}\text { Silencing of stathmin gene can increase } \\
\text { sensitivity of ESCC to paclitaxel and } \\
\text { vincristine through G2/M phase block }\end{array}$ \\
\hline Zhu [81] & & Yes & No & Paclitaxel & $\begin{array}{l}\text { Stathmin silencing by siRNA enhances } \\
\text { sensitivity of esophageal cancer cells } \\
\text { Eca-109 to paclitaxel and induces } \\
\text { apoptosis }\end{array}$ \\
\hline Balasubramani [83] & Breast cancer & Yes & No & Taxol & $\begin{array}{l}\text { Stathmin overexpression protects the cells } \\
\text { from taxol-induced abnormal mitoses, } \\
\text { and thus induces taxol resistance }\end{array}$ \\
\hline Miceli [48] & & Yes & No & Taxol & $\begin{array}{l}\text { Combination of anti-stathmin therapy and } \\
\text { taxol has a more profound inhibition of } \\
\text { tumorigenicity }\end{array}$ \\
\hline Oda [84] & & Yes & No & Zoledronic acid; gefitinib & $\begin{array}{l}\text { Down-regulation of stathmin contributes } \\
\text { to the effect that combined treatment of } \\
\text { Zoledronic acid (Zol) and gefitinib inhib- } \\
\text { its both invasion and cell proliferation of } \\
\text { the bone-seeking clone of breast cancer }\end{array}$ \\
\hline Meng [61] & Gastric cancer & Yes & No & Docetaxel & $\begin{array}{l}\text { Stathmin siRNA can improve the che- } \\
\text { mosensitivity of gastric cancer cells to } \\
\text { docetaxel and promote apoptosis }\end{array}$ \\
\hline Li [24] & & Yes & No & Docetaxel & $\begin{array}{l}\text { Stathmin mediates docetaxel resistance in } \\
\text { transcription factor forkhead box protein } \\
\text { M1 (FOXM1)FOXM1-silenced gastric } \\
\text { cancer cells }\end{array}$ \\
\hline Liu [25] & & Yes & No & Docetaxel & $\begin{array}{l}\text { Inhibition of stathmin enhances the inhibi- } \\
\text { tory effects of docetaxel on the prolifera- } \\
\text { tion of gastric cancer cells }\end{array}$ \\
\hline Werner [85] & Endometrial carcinoma & Yes & Yes & Paclitaxel & $\begin{array}{l}\text { Knock-down of stathmin improves } \\
\text { sensitivity to paclitaxel in endometrial } \\
\text { carcinoma cells }\end{array}$ \\
\hline Wosnitzer [35] & Bladder cancer & No & Yes & Taxane & $\begin{array}{l}\text { Bladder cancer those who have tumors } \\
\text { with low tau/stathmin protein expres- } \\
\text { sion show a better response to taxane }\end{array}$ \\
\hline Mitra [86] & Retinoblastoma & Yes & Yes & Paclitaxel & $\begin{array}{l}\text { Inhibition of stathmin enhances the cyto- } \\
\text { toxic effect of paclitaxel }\end{array}$ \\
\hline Song [63] & Glioma & Yes & No & Temozolomide & $\begin{array}{l}\text { Stathmin silencing inhibits invasion and } \\
\text { enhances chemotherapy sensitivity of } \\
\text { stem cells derived from glioma cells }\end{array}$ \\
\hline Feng [87] & Osteosarcoma & Yes & No & $\begin{array}{l}\text { Arsenic trioxide; } \\
\text { doxorubicin }\end{array}$ & $\begin{array}{l}\text { Down-regulation of stathmin significantly } \\
\text { enhances reversion of ADM resistance in } \\
\text { MG63/dox by As } 2 \mathrm{O} 3\end{array}$ \\
\hline
\end{tabular}


Table 2 continued

\begin{tabular}{|c|c|c|c|c|c|}
\hline Publications & Cancer type & Cell lines & Tissues & Anticancer drugs & Notes \\
\hline Wu [88] & Colorectal cancer & Yes & No & 5-fluorouracil & $\begin{array}{l}\text { Silencing of stathmin significantly } \\
\text { improves chemoresponse to the classi- } \\
\text { cal colorectal cancer therapeutic agent, } \\
5-\mathrm{FU}\end{array}$ \\
\hline Watanabe [18] & Extrahepatic cholangiocarcinoma & Yes & Yes & Paclitaxel & $\begin{array}{l}\text { Silencing of stathmin inhibits proliferation } \\
\text { and increases sensitivity of extrahepatic } \\
\text { cholangiocarcinoma cells to paclitaxel }\end{array}$ \\
\hline
\end{tabular}

$\mathrm{NCl}-\mathrm{H} 1299$ lung adenocarcinoma cell lines, ERK extracellular regulated protein kinases, BCl-2 B-cell lymphoma-2, ESCC esophageal squamous cell cancer, shRNA short hairpin RNA, siRNA small interfering RNA, FOXM1 transcription factor forkhead box protein M1, $A D M$ doxorubicin, $A s_{2} \mathrm{O}_{3}$ arsenic trioxide, 5-FU 5-fluorouracil

gefitinib synergistically inhibits both invasion and cell proliferation of the bone-seeking clone, but not those of the breast cancer MDA-MB-231 cells. Down-regulation of stathmin of these cooperative effects suggests that it may be a promising target molecule for blocking bone metastasis of breast cancer [84].

Research shows that stathmin silencing recovers the chemosensitivity of gastric cancer cells to docetaxel, arrests cells at the sub-G1 stage, induces apoptosis and inhibits the growth of transplantation tumor [61]. Overexpression of transcription factor forkhead box protein M1 (FOXM1) mediates resistance to docetaxel-induced apoptosis in gastric cancers, and stathmin correlates with resistance to docetaxel in FOXM1-silenced gastric cancer cells, indicating that stathmin is effective downstream signal of FOXM1 [24]. Moreover, depletion of stathmin by antisense oligodeoxynucleotide promotes the antitumor effects of docetaxel to gastric cancer cells, and combination treatment of stathmin inhibition and docetaxel shows a synergistic effect [25]. A protein-binding assay reveals that $\mathrm{p} 27$ can be bounded to stathmin of cytoplasm in extrahepatic cholangiocarcinoma (EHCC) cells; moreover, down-regulation of stathmin leads to accumulation of $\mathrm{p} 27$, which suppresses proliferation and promotes sensitivity of EHCC cells to paclitaxel [18]. Knock-down of stathmin enhances sensitivity to paclitaxel in endometrial carcinoma cells [85] and also enhances the cytotoxic effect of paclitaxel to retinoblastoma [86]. Inspiringly, in bacillus Calmette-Guérin refractory bladder cancer, patients who have tumors with low stathmin expression seem to have a better response to taxane therapy [35].

Glioma stem cells (GSCs) are usually resistant to chemotherapy and radiotherapy, but silencing of stathmin can improve the sensitivity of glioma stem cells to temozolomide [63]. Arsenic trioxide $\left(\mathrm{As}_{2} \mathrm{O}_{3}\right)$ and doxorubicin (ADM) combination treatment markedly inhibits cell proliferation of ADM-resistant MG63 (MG63/dox) osteosarcoma cells, and induces apoptosis of MG63/dox cells. Surprisingly, down-regulation of stathmin significantly enhances the reversion of ADM resistance in MG63/ dox by $\mathrm{As}_{2} \mathrm{O}_{3}$, and $\mathrm{As}_{2} \mathrm{O}_{3}$ also reverse $\mathrm{ADM}$ resistance in
MG63/dox cells by down-regulation of stathmin [87]. In addition, 5-FU chemoresponse to the classical colorectal cancer can be improved by silencing of stathmin via a caspase-6 (CASP6)-dependent signal. Interestingly, the function of stathmin is independent of p53 but requires phosphorylations at S25 or S38 [88].

From the above, we can say that assessment of stathmin expression should be considered to use for selection of patients before chemotherapy of some drugs. In addition, research on the relationship between chemoresistance and stathmin should be reinforced, which will be useful to identify a potential chemoresistance marker and to develop a new molecular targeted drug.

\section{Stathmin-dependent molecular targeting therapy based on interfering with stathmin function}

In the last 5 years, many investigations have suggested that stathmin is a potential target for treatment of solid malignant tumors. Especially, a variety of target-specific anti-stathmin effectors, including ribozymes, monoclonal antibody, shRNA and siRNA have been used extensively to decrease expression of stathmin in vitro and vivo to investigate the therapeutic strategies targeted towards stathmin.

As shown in Table 3, these studies point out that downregulation of stathmin significantly reduces cell proliferation, clonal growth, cell motility and metastasis, and increase apoptosis of malignant tumors. For instance, knockdown of stathmin significantly reduces pancreatic cancer cell viability, colony formation, and even retards pancreatic tumor growth in nude mice [27].Although leukemia is not a solid tumor, stathmin silencing still reduces cell proliferation and clonogenicity of U937 and Namalwa leukemia cells [66]. More widely, siRNA-mediated silencing of stathmin has been shown to suppress the proliferation, invasion and metastasis of nasopharyngeal carcinoma (NPC) cells [60], hepatoma [4], retinoblastoma [86], endometrial carcinoma [33], bladder cancer [36] and glioma [89], and significantly induces the apoptosis of tumor cells [54, 60, 62]. Adenovirus-mediated gene transfer of anti-stathmin ribozyme inhibits cell 
Table 3 Summary of stathmin targeted treatment against human tumors

\begin{tabular}{|c|c|c|c|c|}
\hline Publication & Cancer type & Molecule and mechanism & Activity & Notes \\
\hline $\operatorname{Lu}[27]$ & Pancreatic Cancer & $\begin{array}{l}\text { Inhibitors of stathmin } \\
\text { expression }\end{array}$ & mRNA downregulation & $\begin{array}{l}\text { Knockdown of stathmin sig- } \\
\text { nificantly reduces pancreatic } \\
\text { cancer cell viability, colony } \\
\text { formation. Furthermore, silence } \\
\text { of stathmin retards pancreatic } \\
\text { tumor growth in nude mice }\end{array}$ \\
\hline Machado-Neto [29] & Leukemia & siRNA & mRNA downregulation & $\begin{array}{l}\text { Stathmin silencing in U937 } \\
\text { and Namalwa leukemia cells } \\
\text { reduces cell proliferation and } \\
\text { clonogenicity }\end{array}$ \\
\hline Wu [60] & Nasopharyngeal carcinoma & SiRNA & mRNA downregulation & $\begin{array}{l}\text { The siRNA-mediated silencing of } \\
\text { stathmin suppresses prolifera- } \\
\text { tion, invasion and metastasis, } \\
\text { and induces apoptosis of } \\
\text { nasopharyngeal carcinoma } \\
\text { (NPC) cells }\end{array}$ \\
\hline Miceli [48] & Breast cancer & Ribozyme & mRNA downregulation & $\begin{array}{l}\text { Adenovirus-mediated gene trans- } \\
\text { fer of anti-stathmin ribozyme } \\
\text { inhibits proliferation and clono- } \\
\text { genicity in both ER-positive and } \\
\text { ER-negative breast cancer cells }\end{array}$ \\
\hline Wang [77] & & siRNA & mRNA downregulation & $\begin{array}{l}\text { Knockdown of stathmin attenu- } \\
\text { ates down-regulation of miR- } \\
\text { 101-mediated enhancement of } \\
\text { cell growth and metastasis }\end{array}$ \\
\hline Long [55] & & shRNA & mRNA downregulation & $\begin{array}{l}\text { Stathmin promoter-driving } \\
\text { Aurora A shRNA adenoviral sys- } \\
\text { tem has a potential use, which } \\
\text { acts as adjuvant tumor-specific } \\
\text { therapy method, in treatment of } \\
\text { human breast carcinomas }\end{array}$ \\
\hline Nie [3] & Lung cancer & siRNA & mRNA downregulation & $\begin{array}{l}\text { Knockdown of stathmin in lung } \\
\text { cancer cells results in a decrease } \\
\text { in cellular proliferation and } \\
\text { invasion }\end{array}$ \\
\hline Yuan [54] & & Monoclonal antibodies & Protein downregulation & $\begin{array}{l}\text { Monoclonal antibodies against } \\
\text { stathmin inhibit proliferation of } \\
\text { human lung carcinoma QG-56 } \\
\text { cells and result in a significantly } \\
\text { higher apoptosis rate }\end{array}$ \\
\hline Hsieh [4] & Hepatoma & SiRNA & mRNA downregulation & $\begin{array}{l}\text { Silencing of stathmin expression } \\
\text { via RNA interference sup- } \\
\text { presses invasion activity, while } \\
\text { ectopic expression of stathmin } \\
\text { enhances cell invasion and } \\
\text { caused polyploidy of cells }\end{array}$ \\
\hline Wang [16] & $\begin{array}{l}\text { Esophageal squamous cell } \\
\text { carcinoma }\end{array}$ & shRNA-transfected & mRNA downregulation & $\begin{array}{l}\text { Flow cytometry and mitotic index } \\
\text { assays show that knockdown of } \\
\text { stathmin in esophageal squa- } \\
\text { mous cell carcinoma Eca109 } \\
\text { and TE-1 cells leads leads to cell } \\
\text { cycle arrest in G2/M phase }\end{array}$ \\
\hline Liu [13] & & SiRNA & mRNA downregulation & $\begin{array}{l}\text { Knockdown of stathmin with } \\
\text { siRNA impairs cell migration } \\
\text { in esophageal squamous cell } \\
\text { carcinoma KYSE30 and KYSE410 } \\
\text { cells }\end{array}$ \\
\hline Wang [14] & & shRNA plasmid & mRNA downregulation & $\begin{array}{l}\text { Down-regulation of stathmin sig- } \\
\text { nificantly inhibits cell prolifera- } \\
\text { tion, cell migration in vitro, and } \\
\text { tumorigenicity in vivo }\end{array}$ \\
\hline
\end{tabular}


Table 3 continued

\begin{tabular}{|c|c|c|c|c|}
\hline Publication & Cancer type & Molecule and mechanism & Activity & Notes \\
\hline Machado-Neto [62] & Myeloproliferative neoplasms & siRNA & mRNA downregulation & $\begin{array}{l}\text { Silencing of stathmin significantly } \\
\text { reduces cell proliferation and } \\
\text { clonal growth, and increases } \\
\text { apoptosis induced by ruxolitinib }\end{array}$ \\
\hline Mitra [86] & Retinoblastoma & Short interfering RNA & mRNA downregulation & $\begin{array}{l}\text { Short interfering RNA-mediated } \\
\text { transient stathmin down- } \\
\text { regulation results in a marked } \\
\text { inhibition of retinoblastoma cell } \\
\text { proliferation and cell invasion } \\
\text { in vitro }\end{array}$ \\
\hline $\mathrm{He}$ [33] & Endometrial carcinoma & siRNA & mRNA downregulation & $\begin{array}{l}\text { Knockdown of stathmin inhibits } \\
\text { endometrial carcinoma cell } \\
\text { aggressive behaviors. }\end{array}$ \\
\hline Liu [25] & Gastric cancer & $\begin{array}{l}\text { Antisense } \\
\text { oligodeoxynucleotide }\end{array}$ & mRNA downregulation & $\begin{array}{l}\text { Stathmin transfected by antisense } \\
\text { oligodeoxynucleotide signifi- } \\
\text { cantly inhibits proliferation of } \\
\text { gastric cancer SGC } 7901 \text { cells }\end{array}$ \\
\hline Akhtar [91] & & ShRNA & mRNA downregulation & $\begin{array}{l}\text { Stathmin shRNA-treated tumors } \\
\text { are significantly regressed as } \\
\text { compared with that of the } \\
\text { tumor injected with non- } \\
\text { silencing shRNA, proposing a } \\
\text { potential use of local injection } \\
\text { of lentivirus-delivered shRNA for } \\
\text { the treatment of early localized } \\
\text { human gastric carcinoma }\end{array}$ \\
\hline Akhtar [90] & & siRNA & mRNA downregulation & $\begin{array}{l}\text { Lentiviral-mediated RNA interfer- } \\
\text { ence targeting stathmin gene } \\
\text { in human gastric cancer cells } \\
\text { inhibits proliferation in vitro and } \\
\text { tumor growth in vivo }\end{array}$ \\
\hline Hemdan [36] & Bladder cancer & siRNA & mRNA downregulation & $\begin{array}{l}\text { Growth and migration of urinary } \\
\text { bladder cancer cell line T24 cells } \\
\text { are significantly reduced by } \\
\text { stathmin-siRNA }\end{array}$ \\
\hline Dong [89] & Glioma & SiRNA & mRNA downregulation & $\begin{array}{l}\text { When down-regulation of } \\
\text { stathmin, cell viability of glioma } \\
\text { is reduced, apoptosis rate } \\
\text { increases and migration of } \\
\text { vascular endothelial cells is sup- } \\
\text { pressed significantly }\end{array}$ \\
\hline
\end{tabular}

mRNA, messenger RNA, U937 histiocytic lymphoma cells was established by Dr. K. Nilsson's laboratory in 1974, shRNA short hairpin RNA, siRNA small interfering RNA, NPC nasopharyngeal carcinoma, ER estrogen receptor, miR small non-protein-coding regulatory RNAs, Aurora A Aurora kinase A, QG-56 human lung carcinoma QG-56 cells, Eca109 and TE-1 cells esophageal squamous cell carcinoma Eca109 and TE-1 cells, KYSE30 and KYSE410 esophageal squamous cell carcinoma KYSE30 and KYSE410 cells, SGC 7901 gastric cancer SGC 7901 cells, T24 bladder cancer cell line T24 cells

proliferation and clonogenicity in both ER-positive and ER-negative breast cancer cells [48] and knockdown of stathmin can attenuate the miR-101-mediated enhancement of cell growth and metastasis [77]. Stathmin promoter-driving Aurora A shRNA adenoviral system may has potential use, which is considered as adjuvant tumorspecific therapy method, in the treatment of human breast carcinomas [55]. To lung cancer cells, knockdown of stathmin results in a remarkable decrease in cellular proliferation and invasion [3], and monoclonal antibodies against stathmin also inhibit the proliferation of human lung carcinoma QG-56 cells, and even result in a significantly higher apoptosis rate [54]. Moreover, knockdown of stathmin impairs cell proliferation and migration of esophageal squamous cells $[13,14,16]$, and leads to cell cycle arrest in G2/M phase [16].

The depletion of stathmin by antisense oligodeoxynucleotide significantly inhibits the proliferation of gastric cancer cells $[25,90]$. Excitedly, the local injection of stathmin lentivirus-delivered shRNA could be used to treat early localized human gastric carcinoma [91]. Bifunctional small hairpin RNAs (bi-shRNAs) is functional miRNA/ siRNA composite; one study shows that a single intratumoral injection of pbi-sh-stathmin reduces growth of 
tumor xenograft derived from colorectal cancer CCL-247 cells, and also significantly inhibits the growth of tumorgrafts derived from primary melanoma and osteosarcoma xenograft [92]. In human cancers, stathmin is usually overexpressed and anti-stathmin treatment usually reduces cell proliferation, clonal growth, cell motility, metastasis and increases apoptosis. So, an anti-stathmin' targeted therapy could be a potential strategy to cure malignant tumors.

\section{Perspective and limitation}

Up to now, we still know relatively little about how the stathmin regulates tumor proliferation, motility, migration and occurence of metastasis. However, the abnormal expression of stathmin in tumor cells has provided to be a feasible approach for the development of stathmindependent molecular targeting therapy. This way is also fraught with new challenges, for instance, efficient molecules and compounds able to specifically reduce stathmin expression and decrease stathmin activity have not been developed, yet. The clinical application of stathmindependent molecular targeting therapy is lagging way behind, which needs further hard study to explore and discover. In addition, combination treatment of anti-stathmin and other chemotherapy drugs still needs to further study. Anyway, elucidating the function of the stathmin in malignant tumors will effectively disclose the mechanisms of tumor progress and metastasis as well as greatly promote the development of new anticancer therapies.

\section{Conclusion}

Stathmin expression has been found to be increased in a variety of cancers and high expression of stathmin can potentially promote cell proliferation, motility and metastasis of malignant tumors. However, many targetspecific anti-stathmin investigations have been demonstrated to reduce cell proliferation, clonal growth, cell motility and metastasis, and to increase apoptosis of malignant tumors. Whether or not stathmin proves to be a significant therapeutic target, the identification of specific target, development of effective therapeutic drugs and construction of drug delivery vehicles, will all bring a new challenge. Hopefully, this understanding predicts that stathmin-dependent molecular targeting therapy for malignant tumor will soon come out.

\footnotetext{
Abbreviations

ADM: doxorubicin; AGS: gastric adenocarcinomas cell lines; Akt: v-akt murine thymoma viral oncogene; ANKHD1: Ankyrin Repeat and KH Domain Containing 1 protein; $\mathrm{As} 2 \mathrm{O} 3$ : arsenic trioxide; $\mathrm{BCl}-2$ : $\mathrm{B}$-cell lymphoma-2; $\mathrm{BE}(2)-\mathrm{C}$ : neuroblastoma cell lines; bi-shRNAs: bifunctional small hairpin RNAs; CCL-247: human colorectal cancer cells; CASP6: caspase-6; CDC2: cyclin-dependent kinase 1; CDK: cyclin dependent kinase; CDK5: cyclin-dependent kinase-5; CIN3: cervical intraepithelial neoplasias 3; CITs: indoly-chalcones; CREB1: leucine zipper transcription factor; DNA: deoxyribonucleic acid; DNA-PKCS: cataIytic subunit of the DNA-dependent protein kinase; 2-DE: two-dimensional electrophoresis; 2-D DIGE: two dimension difference gel electrophoresis;
}

E1: colorectal cancer cell lines; E2F1: transcription factor 1; EC: esophageal carcinoma; Eca109: esophageal squamous cell carcinoma cell lines; EC9706: esophageal squamous cell carcinoma cell lines; EHCC: extrahepatic cholangiocarcinoma; ELISA: enzyme-linked immunosorbent assay; EOC: epithelial ovarian carcinomas; ESCC: esophageal squamous cell carcinoma; EF1a: EF1a promoter; E2F1: E2F transcription factor 1; EMT: epithelial-mesenchymal transition; ER: estrogen receptor; ERK: extracellular regulated protein kinases; 5-FU: 5-fluorouracil; FISH: fluorescence in situ hybridization; FCM: low cytometry; FOXM1: transcription factor forkhead box protein M1; FTE: fallopian tube epithelium; GSCs: glioma stem cells; HCC: hepatocellular carcinoma; HCT-1 16: colorectal cancer cell lines; HepG2: hepatocellular carcinoma cell line; HIF-1a: hypoxia-inducible factor-1; HSP90: Heat shock protein 90; IGF-1R: insulin-like growth factor-1 receptor; IHC: immunohistochemistry; ISH: in situ hybridization; JAK: Janus Kinase; JNK: c-JunN-terminalkinase.

\section{Authors' contributions}

$\mathrm{RB}$ and LH carried out the literature search, and CX participated in the literature analysis. RB and YS wrote the manuscript. All authors read and approved the final manuscript.

\section{Author details}

${ }^{1}$ Department of Respiratory Medicine, First Affiliated Hospital, Xi'an Medical University, Xi'an, China. ${ }^{2}$ Department of Respiratory Medicine, Gansu Provincial Hospital, Lanzhou, China. ${ }^{3}$ Department of Respiratory Medicine, Second Affiliated Hospital, Xi'an Jiaotong University, Xi'an, China.

\section{Acknowledgements}

This work was supported by Technology Research and Development Plan of Gansu Province (0912TCYA016). The authors wish to thank Drs. Gao Wenlong and Wu Dianlei for their critical comments provided during the preparation of this manuscript and also wish to thank all authors of references.

\section{Competing interests}

The authors declare that they have no competing interests.

\section{Availability of data and materials}

The datasets supporting the conclusions of this article are included within the article.

Received: 2 May 2016 Accepted: 3 August 2016

Published online: 27 September 2016

\section{References}

1. Biaoxue R, Xiguang C, Shuanying Y, Wei L, Zongjuan M. EphA2-dependent molecular targeting therapy for malignant tumors. Curr Cancer Drug Targets. 2011;11(9):1082-97.

2. Chen $X, W u Y$, Dong H, Zhang CY, Zhang Y. Platinum-based agents for individualized cancer treatment. Curr Mol Med. 2013;13(10):1603-12.

3. Nie W, Xu MD, Gan L, Huang H, Xiu Q, Li B. Overexpression of stathmin 1 is a poor prognostic biomarker in non-small cell lung cancer. Lab Invest. 2015;95(1):56-64.

4. Hsieh SY, Huang SF, Yu MC, Yeh TS, Chen TC, Lin YJ, Chang CJ, Sung CM, Lee YL, Hsu CY. Stathmin1 overexpression associated with polyploidy, tumor-cell invasion, early recurrence, and poor prognosis in human hepatoma. Mol Carcinog. 2010;49(5):476-87.

5. Belletti B, Baldassarre G. Stathmin a protein with many tasks. New biomarker and potential target in cancer. Expert Opin Ther Targets. 2011;15(11):1249-66.

6. Rana S, Maples PB, Senzer N, Nemunaitis J. Stathmin 1: a novel therapeutic target for anticancer activity. Expert Rev Anticancer Ther. 2008:8(9):1461-70.

7. Reyes H, Bosquet J, Stephan J, McDonald M, Leslie K. Stathmin overexpression correlates with poor prognosis in patients with endometrial cancer. Gynecol Oncol. 2015;137:66.

8. Sonego M, Schiappacassi M, Lovisa S, Dall'Acqua A, Bagnoli M, Lovat F, Libra M, D'Andrea S, Canzonieri V, Militello L. Stathmin regulates mutant p53 stability and transcriptional activity in ovarian cancer. EMBO Mol Med. 2013;5(5):707-22. 
9. Lachkar S, Lebois M, Steinmetz MO, Guichet A, Lal N, Curmi PA, Sobel A, Ozon S. Drosophila stathmins bind tubulin heterodimers with high and variable stoichiometries. J Biol Chem. 2010;285(15):11667-80.

10. Lu Y, Liu C, Xu YF, Cheng H, Shi S, Wu CT, Yu XJ. Stathmin destabilizing microtubule dynamics promotes malignant potential in cancer cells by epithelial-mesenchymal transition. Hepatobiliary Pancreat Dis Int. 2014;13(4):386-94.

11. Sun R, Liu Z, Wang L, Lv W, Liu J, Ding C, Yuan Y, Lei G, Xu C. Overexpression of stathmin is resistant to paclitaxel treatment in patients with nonsmall cell lung cancer. Tumour Biol. 2015;36(9):7195-204.

12. Akhtar J, Wang Z, Jiang WP, Bi MM, Zhang ZP. Stathmin overexpression identifies high risk for lymphatic metastatic recurrence in pNO esophageal squamous cell carcinoma patients. J Gastroenterol Hepatol. 2014;29(5):944-50.

13. Liu F, Sun YL, Xu Y, Wang LS, Zhao XH. Expression and phosphorylation of stathmin correlate with cell migration in esophageal squamous cell carcinoma. Oncol Rep. 2013;29(2):419-24.

14. Wang F, Wang LX, Li SL, Li K, He W, Liu HT, Fan QX. Downregulation of stathmin is involved in malignant phenotype reversion and cell apoptosis in esophageal squamous cell carcinoma. J Surg Oncol. 2011;103(7):704-15.

15. Wang F, Xuan XY, Yang X, Cao L, Pang LN, Zhou R, Fan QX, Wang LX. Stathmin is a marker of progression and poor prognosis in esophageal carcinoma. Asian Pac J Cancer Prev. 2014;15(8):3613-8.

16. Wang S, Akhtar J, Wang Z. Anti-STMN1 therapy improves sensitivity to antimicrotubule drugs in esophageal squamous cell carcinoma. Tumour Biol. 2015;36(10):7797-806.

17. Baquero MT, Hanna JA, Neumeister V, Cheng H, Molinaro AM, Harris LN, Rimm DL. Stathmin expression and its relationship to microtubule-associated protein tau and outcome in breast cancer. Cancer. 2012;118(19):4660-9.

18. Watanabe A, Suzuki H, Yokobori T, Tsukagoshi M, Altan B, Kubo N, Suzuki S, Araki K, Wada S, Kashiwabara K, et al. Stathmin 1 regulates p27 expression, proliferation and drug resistance, resulting in poor clinical prognosis in cholangiocarcinoma. Cancer Sci. 2014;105(6):690-6.

19. Ahn EY, Yoo JE, Rhee H, Kim MS, Choi J, Ko JE, Lee JS, Park YN. Increased expression of stathmin and elongation factor 1 alpha in precancerous nodules with telomere dysfunction in hepatitis B viral cirrhotic patients. J Transl Med. 2014;12:154

20. Chen YL, Uen YH, Li CF, Horng KC, Chen LR, Wu WR, Tseng HY, Huang HY, Wu LC, Shiue YL. The E2F transcription factor 1 transactives stathmin 1 in hepatocellular carcinoma. Ann Surg Oncol. 2013;20(12):4041-54.

21. Batsaikhan BE, Yoshikawa K, Kurita N, Iwata T, Takasu C, Kashihara H, Shimada M. Expression of Stathmin1 in gastric adenocarcinoma. Anticancer Res. 2014;34(8):4217-21.

22. Kang W, Tong JH, Chan AW, Lung RW, Chau SL, Wong QW, Wong N, Yu J, Cheng AS, To KF. Stathmin1 plays oncogenic role and is a target of microRNA-223 in gastric cancer. PLoS ONE. 2012;7(3):e33919.

23. Ke B, Wu LL, Liu N, Zhang RP, Wang CL, Liang H. Overexpression of stathmin 1 is associated with poor prognosis of patients with gastric cancer. Tumour Biol. 2013;34(5):3137-45.

24. Li X, Yao R, Yue L, Qiu W, Qi W, Liu S, Yao Y, Liang J. FOXM1 mediates resistance to docetaxel in gastric cancer via up-regulating stathmin. J Cell Mol Med. 2014;18(5):811-23.

25. Liu X, Liu H, Liang J, Yin B, Xiao J, Li J, Feng D, Li Y. Stathmin is a potential molecular marker and target for the treatment of gastric cancer. Int J Clin Exp Med. 2015;8(4):6502-9.

26. Li J, Kong F, Wu K, Song K, He J, Sun W. miR-193b directly targets STMN1 and UPA genes and suppresses tumor growth and metastasis in pancreatic cancer. Mol Med Rep. 2014;10(5):2613-20.

27. Lu Y, Liu C, Cheng H, Xu Y, Jiang J, Xu J, Long J, Liu L, Yu X. Stathmin, interacting with $\mathrm{Nf}-\mathrm{kappaB}$, promotes tumor growth and predicts poor prognosis of pancreatic cancer. Curr Mol Med. 2014;14(3):328-39.

28. Schimmack S, Taylor A, Lawrence B, Schmitz-Winnenthal H, Fischer L, Buchler MW, Modlin IM, Kidd M, Tang LH. Stathmin in pancreatic neuroendocrine neoplasms: a marker of proliferation and PI3 K signaling. Tumour Biol. 2015;36(1):399-408.

29. Machado-Neto JA, de Melo Campos P, Favaro P, Lazarini M, Lorand-Metze I, Costa FF, OlallaSaad ST, Traina F. Stathmin 1 is involved in the highly proliferative phenotype of high-risk myelodysplastic syndromes and acute leukemia cells. Leuk Res. 2014;38(2):251-7.
30. Hsu HP, Li CF, Lee SW, Wu WR, Chen TJ, Chang KY, Liang SS, Tsai CJ, Shiue YL. Overexpression of stathmin 1 confers an independent prognostic indicator in nasopharyngeal carcinoma. Tumour Biol. 2014;35(3):2619-29.

31. Birnie KA, Yip YY, Ng DC, Kirschner MB, Reid G, Prele CM, Musk AW, Lee YC, Thompson PJ, Mutsaers SE, et al. Loss of miR-223 and JNK signaling contribute to elevated stathmin in malignant pleural mesothelioma. Mol Cancer Res. 2015;13(7):1106-18.

32. Howitt BE, Nucci MR, Drapkin R, Crum CP, Hirsch MS. Stathmin-1 expression as a complement to 16 helps identify high-grade cervical intraepithelial neoplasia with increased specificity. Am J Surg Pathol. 2013;37(1):89-97.

33. He X, Liao Y, Lu W, Xu G, Tong H, Ke J, Wan X. Elevated STMN1 promotes tumor growth and invasion in endometrial carcinoma. Tumor Biol. 2016:1-8.

34. Wik E, Birkeland E, Trovik J, Werner HM, Hoivik EA, Mjos S, Krakstad C, Kusonmano K, Mauland K, Stefansson IM, et al. High phosphoStathmin(Serine38) expression identifies aggressive endometrial cancer and suggests an association with PI3 K inhibition. Clin Cancer Res. 2013;19(9):2331-41.

35. Wosnitzer MS, Domingo-Domenech J, Castillo-Martin M, Ritch C, Mansukhani M, Petrylack DP, Benson MC, McKiernan JM, Cordon-Cardo C. Predictive value of microtubule associated proteins tau and stathmin in patients with nonmuscle invasive bladder cancer receiving adjuvant intravesical taxane therapy. J Urol. 2011;186(5):2094-100.

36. Hemdan T, Linden M, Lind SB, Namuduri AV, Sjostedt E, de Stahl TD, Asplund A, Malmstrom PU, Segersten U. The prognostic value and therapeutic target role of stathmin-1 in urinary bladder cancer. Br J Cancer. 2014;111(6):1180-7.

37. Bhagirath D, Abrol N, Khan R, Sharma M, Seth A, Sharma A. Expression of CD147, BIGH3 and Stathmin and their potential role as diagnostic marker in patients with urothelial carcinoma of the bladder. Clin Chim Acta. 2012:413(19-20):1641-6.

38. Tan HT, Wu W, Ng YZ, Zhang X, Yan B, Ong CW, Tan S, Salto-Tellez M, Hooi SC, Chung MC. Proteomic analysis of colorectal cancer metastasis: stathmin-1 revealed as a player in cancer cell migration and prognostic marker. J Proteome Res. 2012;11(2):1433-45.

39. Marie SK, Oba-Shinjo SM, da Silva R, Gimenez M, Nunes Reis G, Tassan JP, Rosa JC, Uno M. Stathmin involvement in the maternal embryonic leucine zipper kinase pathway in glioblastoma. Proteome Sci. 2016;14:6.

40. Ng DCH, Byrne F. Stathmin and cancer. In: Cytoskeleton and Human Disease. Berlin: Springer; 2012. pp. 259-84.

41. Uchida S, Shumyatsky GP. Deceivingly dynamic: learning-dependent changes in stathmin and microtubules. Neurobiol Learn Mem. 2015;124:52-61.

42. Li N, Jiang P, Du W, Wu Z, Li C, Qiao M, Yang X, Wu M. Siva1 suppresses epithelial-mesenchymal transition and metastasis of tumor cells by inhibiting stathmin and stabilizing microtubules. Proc Natl Acad Sci USA. 2011;108(31):12851-6.

43. Alesi GN, Jin L, Li D, Magliocca KR, Kang Y, Chen ZG, Shin DM, Khuri FR, Kang S. RSK2 signals through stathmin to promote microtubule dynamics and tumor metastasis. Oncogene. 2016.

44. Lin X, Tang M, Tao Y, Li L, Liu S, Guo L, Li Z, Ma X, Xu J, Cao Y. Epstein-Barr virus-encoded LMP1 triggers regulation of the ERK-mediated Op18/ stathmin signaling pathway in association with cell cycle. Cancer Sci. 2012;103(6):993-9.

45. Takahashi K, Suzuki K. Membrane transport of WAVE2 and lamellipodia formation require Pak1 that mediates phosphorylation and recruitment of stathmin/Op18 to Pak1-WAVE2-kinesin complex. Cell Signal. 2009;21(5):695-703.

46. Silva VC, Cassimeris L. Stathmin and microtubules regulate mitotic entry in HeLa cells by controlling activation of both Aurora kinase A and Plk1. Mol Biol Cell. 2013;24(24):3819-31.

47. Wang R, Wang Z, Yang J, Liu X, Wang L, Guo X, Zeng F, Wu M, Li G. LRRC4 inhibits the proliferation of human glioma cells by modulating the expression of STMN1 and microtubule polymerization. J Cell Biochem. 2011;112(12):3621-9.

48. Miceli C, Tejada A, Castaneda A, Mistry SJ. Cell cycle inhibition therapy that targets stathmin in in vitro and in vivo models of breast cancer. Cancer Gene Ther. 2013;20(5):298-307.

49. Berton S, Pellizzari I, Fabris L, D'Andrea S, Segatto I, Canzonieri V, Marconi D, Schiappacassi M, Benevol S, Gattei V, et al. Genetic characterization of 
p27(kip1) and stathmin in controlling cell proliferation in vivo. Cell Cycle. 2014;13(19):3100-11.

50. Tamura K, Yoshie M, Miyajima E, Kano M, Tachikawa E. Stathmin regulates hypoxia-inducible factor-1alpha expression through the mammalian target of rapamycin pathway in ovarian clear cell adenocarcinoma. ISRN Pharmacol. 2013;2013:279593.

51. San-Marina S, Han Y, Liu J, Minden MD. Suspected leukemia oncoproteins CREB1 and LYL1 regulate Op18/STMN1 expression. Biochim Biophys Acta. 2012:1819(11-12):1164-72.

52. Wegiel B, Wang Y, Li M, Jernigan F, Sun L. Novel indolyl-chalcones target stathmin to induce cancer cell death. Cell Cycle. 2016;15(9):1288-94.

53. Chen X, Shen J, Li X, Wang X, Long M, Lin F, Wei J, Yang L, Yang C, Dong $\mathrm{K}$, et al. Rlim, an E3 ubiquitin ligase, influences the stability of Stathmin protein in human osteosarcoma cells. Cell Signal. 2014;26(7):1532-8.

54. Yuan SF, Chen WJ, Zhu LJ, Zheng WE, Chen H, Xiong JP. Effects of monoclonal antibodies against human stathmin combined with paclitaxel on proliferation of the QG-56 human lung carcinoma cell line. Asian Pac J Cancer Prev. 2012;13(6):2967-71.

55. Long M, Yin G, Liu L, Lin F, Wang X, Ren J, Wei J, Dong K, Zhang H. Adenovirus-mediated Aurora A shRNA driven by stathmin promoter suppressed tumor growth and enhanced paclitaxel chemotherapy sensitivity in human breast carcinoma cells. Cancer Gene Ther. 2012;19(4):271-81.

56. Karst AM, Levanon K, Duraisamy S, Liu JF, Hirsch MS, Hecht JL, Drapkin R. Stathmin 1, a marker of PI3 K pathway activation and regulator of microtubule dynamics, is expressed in early pelvic serous carcinomas. Gynecol Oncol. 2011;123(1):5-12.

57. Koff JL, Ramachandiran S, Bernal-Mizrachi L. A time to kill: targeting apoptosis in cancer. Int J Mol Sci. 2015;16(2):2942-55.

58. Zhao E, Amir M, Lin Y, Czaja MJ. Stathmin mediates hepatocyte resistance to death from oxidative stress by down regulating JNK. PLOS ONE. 2014;9(10):e109750.

59. Li J, Hu GH, Kong FJ, Wu KM, He B, Song K, Sun WJ. Reduced STMN1 expression induced by RNA interference inhibits the bioactivity of pancreatic cancer cell line Panc-1. Neoplasma. 2014;61(2):144-52.

60. Wu Y, Tang M, Weng X, Yang L, Xu W, Yi W, Gao J, Bode AM, Dong Z, Cao Y. A combination of paclitaxel and siRNA-mediated silencing of Stathmin inhibits growth and promotes apoptosis of nasopharyngeal carcinoma cells. Cell Oncol (Dordr). 2014;37(1):53-67.

61. Meng ZJ, Tao K. Enhancement of chemosensitivity by stathmin-1 silencing in gastric cancer cells in situ and in vivo. Oncol Res. 2016;23(1):35-41.

62. Machado-Neto JA, de Melo Campos P, Favaro P, Lazarini M, da Silva Santos Duarte A, Lorand-Metze I, Costa FF, Saad ST, Traina F. Stathmin 1 inhibition amplifies ruxolitinib-induced apoptosis in JAK2V617F cells. Oncotarget. 2015;6(30):29573-84

63. Song Y, Mu L, Han X, Liu X, Fu S. siRNA targeting stathmin inhibits invasion and enhances chemotherapy sensitivity of stem cells derived from glioma cell lines. Acta Biochim Biophys Sin (Shanghai). 2014;46(12):1034-40.

64. Byrne FL, Yang L, Phillips PA, Hansford LM, Fletcher JI, Ormandy CJ, McCarroll JA, Kavallaris M. RNAi-mediated stathmin suppression reduces lung metastasis in an orthotopic neuroblastoma mouse model. Oncogene. 2014;33(7):882-90.

65. Sabherwal Y, Mahajan N, Helseth DL, Gassmann M, Shi H, Zhang M. PDEF downregulates stathmin expression in prostate cancer. Int J Oncol. 2012;40(6):1889-99.

66. Machado-Neto JA, Lazarini M, Favaro P, de Melo Campos P, ScopimRibeiro R, Franchi Junior GC, Nowill AE, Lima PR, Costa FF, Benichou S, et al. ANKHD1 silencing inhibits Stathmin 1 activity, cell proliferation and migration of leukemia cells. Biochim Biophys Acta. 2015;1853(3):583-93.

67. Knight LM, Stakaityte G, Wood JJ, Abdul-Sada H, Griffiths DA, Howell GJ, Wheat R, Blair GE, Steven NM, Macdonald A, et al. Merkel cell polyomavirus small $T$ antigen mediates microtubule destabilization to promote cell motility and migration. J Virol. 2015:89(1):35-47.

68. Acunzo M, Romano G, Wernicke D, Croce CM. MicroRNA and cancer-a brief overview. Adv Biol Regul. 2015;57:1-9.

69. Hassan MK, Watari H, Mitamura T, Mohamed Z, El-Khamisy SF, Ohba Y, Sakuragi N. P18/Stathmin 1 is regulated by miR-31 in ovarian cancer in response to taxane. Oncoscience. 2015;2(3):294-308.

70. Sun Q, Liu T, Zhang T, Du S, Xie GX, Lin X, Chen L, Yuan Y. MiR-101 sensitizes human nasopharyngeal carcinoma cells to radiation by targeting stathmin 1. Mol Med Rep. 2015;11(5):3330-6.
71. Chen J, Abi-Daoud M, Wang A, Yang X, Zhang X, Feilotter HE, Tron VA. Stathmin 1 is a potential novel oncogene in melanoma. Oncogene. 2013:32(10):1330-7.

72. Nyhan MJ, O'Donovan TR, Boersma AW, Wiemer EA, McKenna SL. MiR193b promotes autophagy and non-apoptotic cell death in oesophageal cancer cells. BMC Cancer. 2016;16(1):101.

73. Kiga K, Mimuro H, Suzuki M, Shinozaki-Ushiku A, Kobayashi T, Sanada T, Kim M, Ogawa M, Iwasaki YW, Kayo H, et al. Epigenetic silencing of miR-210 increases the proliferation of gastric epithelium during chronic Helicobacter pylori infection. Nat Commun. 2014;5:4497.

74. Aucher A, Rudnicka D, Davis DM. MicroRNAs transfer from human macrophages to hepato-carcinoma cells and inhibit proliferation. J Immunol. 2013;191(12):6250-60.

75. Song Y, Mu L, Han X, Li Q, Dong B, Li H, Liu X. MicroRNA-9 inhibits vasculogenic mimicry of glioma cell lines by suppressing stathmin expression. J Neurooncol. 2013;115(3):381-90.

76. Xu Y, An Y, Wang Y, Zhang C, Zhang H, Huang C, Jiang H, Wang $X$, Li X. miR-101 inhibits autophagy and enhances cisplatin-induced apoptosis in hepatocellular carcinoma cells. Oncol Rep. 2013;29(5):2019-24.

77. Wang R, Wang HB, Hao CJ, Cui Y, Han XC, Hu Y, Li FF, Xia HF, Ma X. MiR-101 is involved in human breast carcinogenesis by targeting stathmin1. PLoS ONE. 2012;7(10):e46173.

78. Lin X, Liao Y, Xie J, Liu S, Su L, Zou H. Op18/stathmin is involved in the resistance of taxol among different epithelial carcinoma cell lines. Cancer Biother Radiopharm. 2014;29(9):376-86.

79. Lin X, Liao Y, Chen X, Long D, Yu T, Shen F. Regulation of oncoprotein 18/ stathmin signaling by ERK concerns the resistance to taxol in nonsmall cell lung cancer cells. Cancer Biother Radiopharm. 2016;31(2):37-43.

80. Han ZX, Wang HM, Jiang G, Du XP, Gao XY, Pei DS. Overcoming paclitaxel resistance in lung cancer cells via dual inhibition of stathmin and $\mathrm{BCl}-2$. Cancer Biother Radiopharm. 2013;28(5):398-405.

81. Zhu HW, Jiang D, Xie ZY, Zhou MH, Sun DY, Zhao YG. Effects of stathmin 1 silencing by siRNA on sensitivity of esophageal cancer cells Eca-109 to paclitaxel. Genet Mol Res. 2015;14(4):18695-702.

82. Feng W, Xiaoyan X, Xuan Y, Xiangke L, Zichang Y, Ran Z, Liuxing W, Qingxia F. Silencing stathmin-modulating efficiency of chemotherapy for esophageal squamous cell cancer with paclitaxel. Cancer Gene Ther. 2015;22(3):115-21.

83. Balasubramani M, Nakao C, Uechi GT, Cardamone J, Kamath K, Leslie KL, Balachandran R, Wilson L, Day BW, Jordan MA. Characterization and detection of cellular and proteomic alterations in stable stathmin-overexpressing, taxol-resistant BT549 breast cancer cells using offgel IEF/PAGE difference gel electrophoresis. Mutat Res. 2011;722(2):154-64.

84. Oda M, Iwaya K, Kikuchi R, Kobayashi T, Yoneda T, Nishikawa K, Matsubara $\mathrm{O}, \mathrm{Kohno}$ N. Stathmin is involved in the cooperative effect of Zoledronic acid and gefitinib on bone homing breast cancer cells in vitro. J Bone Oncol. 2012;1(2):40-6.

85. Werner HM, Trovik J, Halle MK, Wik E, Akslen LA, Birkeland E, Bredholt T, Tangen IL, Krakstad C, Salvesen HB. Stathmin protein level, a potential predictive marker for taxane treatment response in endometrial cancer. PLoS ONE. 2014;9(2):e90141.

86. Mitra M, Kandalam M, Sundaram CS, Verma RS, Maheswari UK, Swaminathan S, Krishnakumar S. Reversal of stathmin-mediated microtubule destabilization sensitizes retinoblastoma cells to a low dose of antimicrotubule agents: a novel synergistic therapeutic intervention. Invest Ophthalmol Vis Sci. 2011;52(8):5441-8.

87. Feng T, Qiao G, Feng L, Qi W, Huang Y, Yao Y, Shen Z. Stathmin is key in reversion of doxorubicin resistance by arsenic trioxide in osteosarcoma cells. Mol Med Rep. 2014;10(6):2985-92.

88. Wu W, Tan XF, Tan HT, Lim TK, Chung MC. Unbiased proteomic and transcript analyses reveal that stathmin-1 silencing inhibits colorectal cancer metastasis and sensitizes to 5-fluorouracil treatment. Mol Cancer Res. 2014;12(12):1717-28.

89. Dong B, Mu L, Qin X, Qiao W, Liu X, Yang L, Xue L, Rainov NG. Stathmin expression in glioma-derived microvascular endothelial cells: a novel therapeutic target. Oncol Rep. 2012;27(3):714-8.

90. Akhtar J, Wang Z, Zhang ZP, Bi MM. Lentiviral-mediated RNA interference targeting stathmin 1 gene in human gastric cancer cells inhibits proliferation in vitro and tumor growth in vivo. J Transl Med. 2013;11:212. 
91. Akhtar J, Wang Z, Yu C, Zhang ZP. Effectiveness of local injection of lentivirus-delivered stathmin 1 and stathmin 1 shRNA in human gastric cancer xenograft mouse. J Gastroenterol Hepatol. 2014;29(9):1685-91.
92. Phadke AP, Jay CM, Wang Z, Chen S, Liu S, Haddock C, Kumar P, Pappen BO, Rao DD, Templeton NS, et al. In vivo safety and antitumor efficacy of bifunctional small hairpin RNAs specific for the human stathmin 1 oncoprotein. DNA Cell Biol. 2011;30(9):715-26.

Submit your next manuscript to BioMed Central and we will help you at every step:

- We accept pre-submission inquiries

- Our selector tool helps you to find the most relevant journal

- We provide round the clock customer support

- Convenient online submission

- Thorough peer review

- Inclusion in PubMed and all major indexing services

- Maximum visibility for your research

Submit your manuscript at www.biomedcentral.com/submit 